This item was submitted to Loughborough's Research Repository by the author.

Items in Figshare are protected by copyright, with all rights reserved, unless otherwise indicated.

\title{
Comparing London and Frankfurt as world cities: a relational study of contemporary urban change
}

PLEASE CITE THE PUBLISHED VERSION

PUBLISHER

(C) Anglo-German Foundation for the Study of Industrial Society

\section{VERSION}

VoR (Version of Record)

\section{LICENCE}

CC BY-NC-ND 4.0

\section{REPOSITORY RECORD}

Beaverstock, Jonathan V., Michael Hoyler, Kathryn Pain, and Peter J. Taylor. 2019. "Comparing London and Frankfurt as World Cities: A Relational Study of Contemporary Urban Change". figshare.

https://hdl.handle.net/2134/9572. 
This item was submitted to Loughborough's Institutional Repository (https://dspace.lboro.ac.uk/) by the author and is made available under the following Creative Commons Licence conditions.

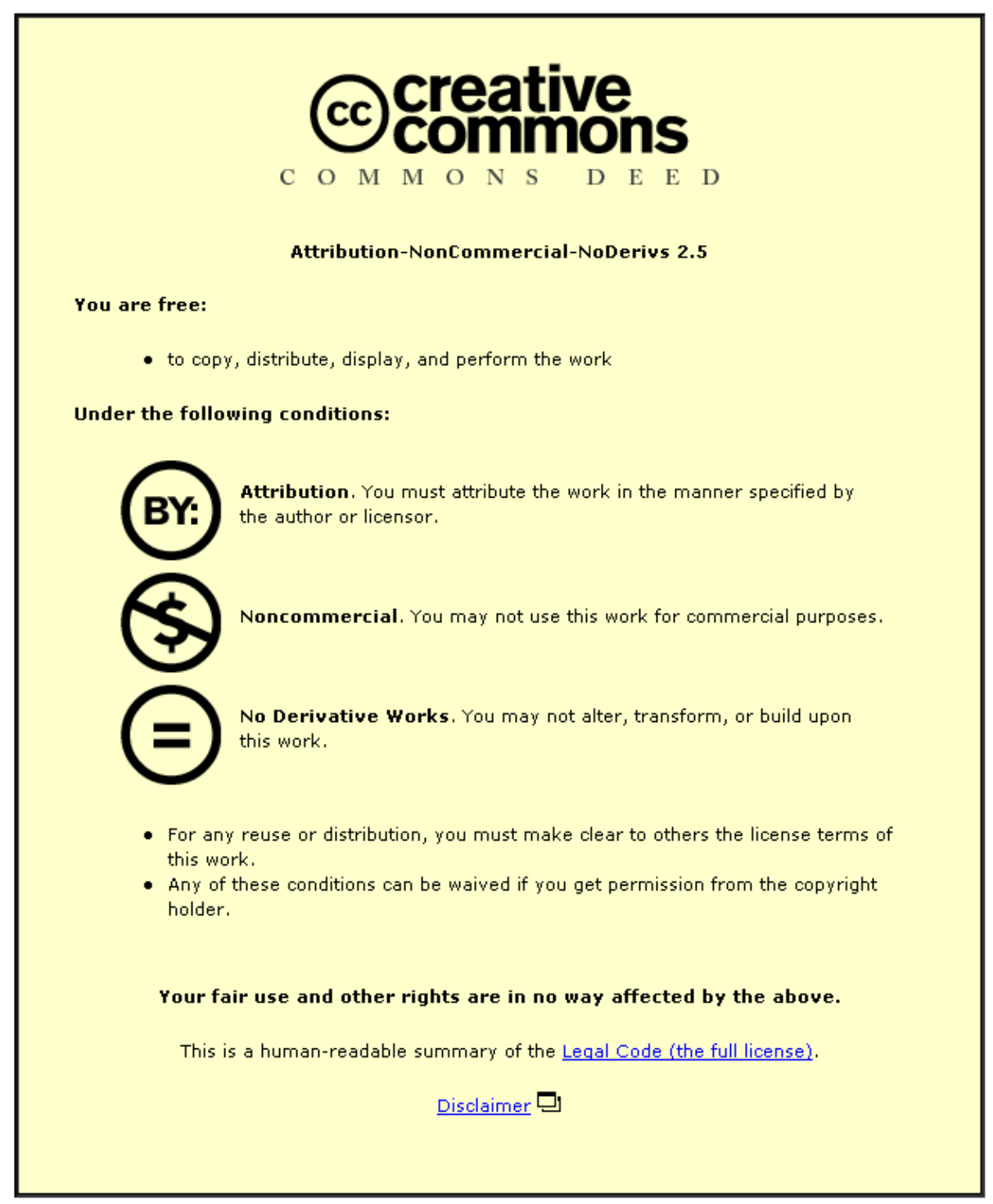

For the full text of this licence, please go to: http://creativecommons.org/licenses/by-nc-nd/2.5/ 

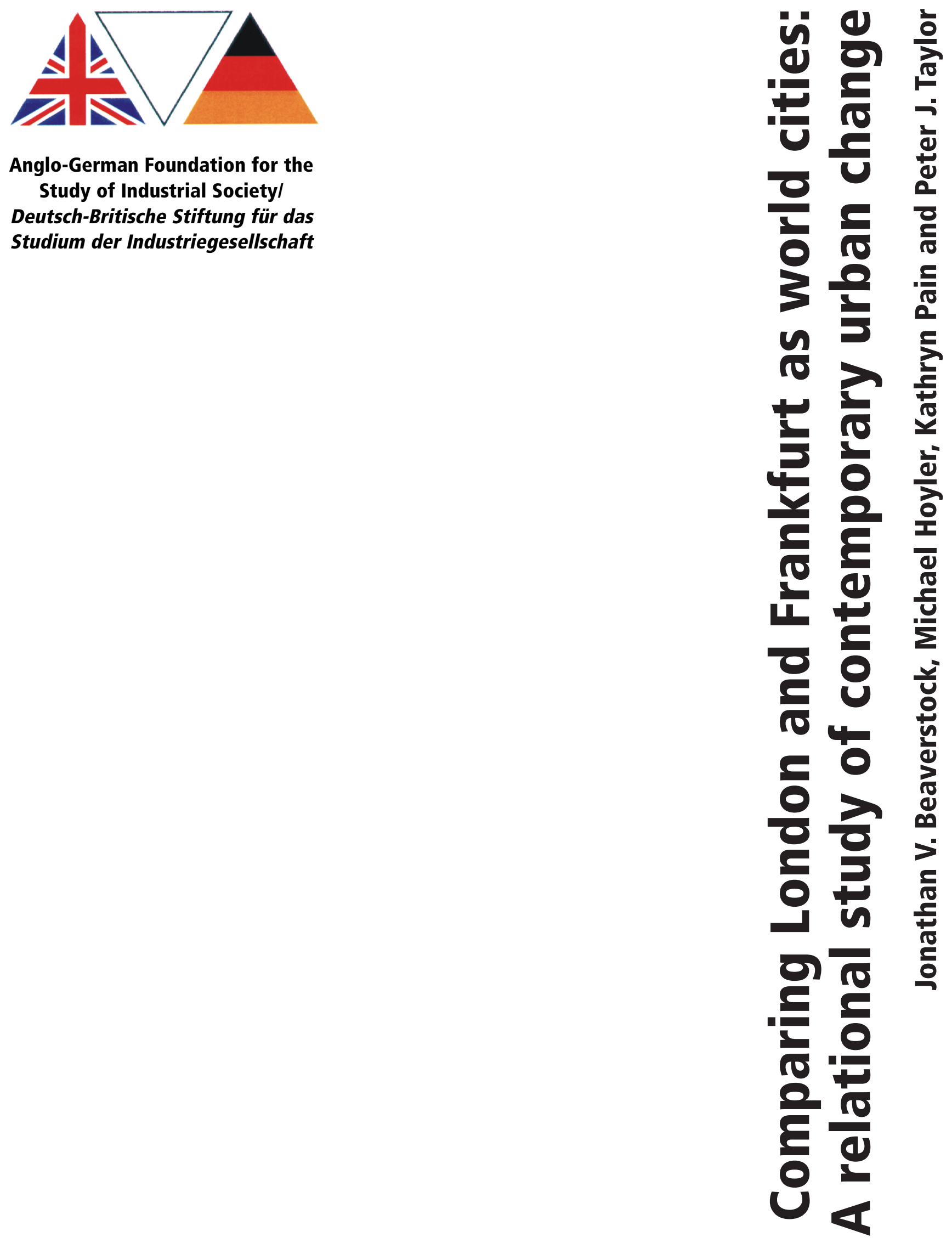

Anglo-German Foundation for the Study of Industrial Society/ Deutsch-Britische Stiftung für das Studium der Industriegesellschaft 


\title{
Comparing London and Frankfurt as world cities: \\ A relational study of contemporary urban change
}

\author{
Jonathan V. Beaverstock*, Michael Hoyler**, \\ Kathryn Pain*, Peter J. Taylor* \\ * Department of Geography, Loughborough University, \\ Loughborough, LE11 3TU, United Kingdom \\ ** Geographisches Institut, Universität Heidelberg, \\ Berliner Strasse 48, 69120 Heidelberg, Germany
}

August 2001

Anglo-German Foundation

for the Study of Industrial Society 
The Anglo-German Foundation's mission is to enhance mutual British-German understanding and co-operation by supporting research and discussion of the challenges presented in both countries by changing patterns of economic activity.

We aim to promote best practice in each country by providing access to information, ideas and experience from the other.

The views and opinions expressed in Anglo-German Foundation publications are those of their respective authors, and do not necessarily represent the views of the Foundation.

Die zentrale Aufgabe der Stiftung ist die Verbesserung des Verständnisses und der Zusammenarbeit zwischen Deutschland und Großbritannien. Wir verfolgen diese Aufgabe durch die Förderung von Forschung und Diskussion zu Themen, die durch den wirtschaftlichen Wandel gestellt werden.

In beiden Ländern unterstützt die Stiftung die Verbreitung erfolgreicher politischer und wirtschaftlicher Praxis, indem Sie Zugang zu Informationen, Ideen und Erfahrungen aus dem jeweils anderen Land ermöglicht.

Die Verantwortung für den Inhalt der Publikationen der Deutsch-Britischen Stiftung liegt bei den jeweiligen Autoren.

๑ 2001 Anglo-German Foundation

\author{
Anglo-German Foundation for the Study of Industrial Societyl \\ Deutsch-Britische Stiftung für das Studium der Industriegesellschaft \\ 17 Bloomsbury Square, London WC1A 2NH \\ Tel: +44 (0)20 74043137 Fax: +44 (0)20 74052071 \\ www.agf.org.uk
}




\section{Contents}

Contents

Acknowledgements iii

Executive summary iv

The euro iv

Complexity iv

Networks v v

1 London and Frankfurt as world cities 1

1.1 Comparing London and Frankfurt 1

1.2 World cities as nodes in a world-wide network of cities 3

1.3 London and Frankfurt in the world city network 4

1.4 Enframing London-Frankfurt relations as competition 6

1.5 Methodology: studying inter-city relations 9

2 The effects of the euro on business relations between London and Frankfurt $\quad 10$

$\begin{array}{lll}2.1 & \text { Contrary findings } & 10\end{array}$

2.2 'The currency is not an issue' 10

2.3 Frankfurt's position in Europe 11

2.4 London remains the premier European financial centre 13

$2.5 \quad$ The need to study complexity 15

3 The complexity of London-Frankfurt relations 16

3.1 'The trouble is it's a huge jigsaw' 16

3.2 The underlying tension: global versus local 17

$\begin{array}{ll}3.3 & \text { Specific tensions in inter-firm competition }\end{array}$

3.4 Resolutions and outcomes in cities 25 
4 London-Frankfurt relations in a network society 27

$\begin{array}{lll}4.1 & \text { The spaces of networks } & 27\end{array}$

$\begin{array}{lll}4.2 & \text { Knowledge networks } & 27\end{array}$

$\begin{array}{lll}4.3 & \text { Cultural networks } & 30\end{array}$

4.4 Power networks 32

$\begin{array}{lll}4.5 & \text { Governance networks } & 34\end{array}$

4.6 The space of inter-city flows in interweaving networks 36

Appendix 1: Firms interviewed in London and Frankfurt 41

London 41

Frankfurt $\quad 42$

Appendix 2: The grade of personnel interview in London and Frankfurt

Appendix 3: Firms' questionnaire 44

'Face-to-face' interview questionnaire $\quad 44$

Telephone questionnaire $\quad 45$

Appendix 4: Institutions interviewed in London and Frankfurt $\quad 46$

London $\quad 46$

Frankfurt $\quad 46$

Appendix 5: Institutions' questionnaire 47

Interim results 47

$\begin{array}{ll}\text { Questions } & 47\end{array}$

$\begin{array}{ll}\text { Bibliography } & 48\end{array}$ 


\section{Acknowledgements}

The authors would like to gratefully thank Professor Peter Meusburger, Department of Geography, University of Heidelberg, for his encouragement and contributions to the planning and organisation of the research and the proof reading and editing of this report.

We also gratefully thank all those representatives of the firms and institutions in London and Frankfurt (listed in Appendices 1 and 4) who gave so much of their valuable time to the interviews and supplied us with the information without which this research would not have been possible. 


\section{Executive summary}

This project has a quite straightforward purpose: to investigate relations between London and Frankfurt with the coming of a single European currency. Generally speaking, we have confirmed a network model of inter-city relations at the expense of the simplistic competition model that dominates so much public discussion of inter-city relations. In this summary we present all the main findings with short commentaries.

\section{The euro}

- The new currency has had no wholesale effects on changing business relations between the two cities.

- $\quad$ Frankfurt's position in Europe is strengthening, but not at the expense of London.

- London remains the main European financial centre.

These are findings that show quite clearly that a simple competitive model is wholly inadequate for understanding London-Frankfurt relations. This is not to say there has not been relative movement between the status of the cities - there has, but this is not indicative of any 'fierce competition' as it has sometimes been portrayed.

\section{Complexity}

- The fundamental tension facing firms in both London and Frankfurt is negotiating trans-border (global) reach against local sensibilities.

- There are other critical tensions in organisation, knowledge production, operationalisation, and locational issues.

- The primary inter-city outcome of this inter-firm competition is a co-operative relation between London and Frankfurt within a wider network.

These findings explore the complexity of London-Frankfurt relations using the idea of tensions that have to be overcome in day-to-day operations in a world city network. This is where we deal with the 'competition/co-operation' conundrum as co-operation between cities operating alongside competition between firms. 


\section{Networks}

- Knowledge networks have the potential to revolutionise spaces of flows and redefine shifting relations between London and Frankfurt.

- Cultural networks are a key determinant of, and stimulus to, inter-city business relations.

- $\quad$ Power networks exhibit shifting relationships and strong mutual dependencies that reflect established patterns of investment.

- Governance networks reach out between the cities regulating and shaping London-Frankfurt business flows through a web of public-private and local-global relationships.

- Interweaving networks are characterised by proximity, connections and complex interdependencies making co-operation integral to inter-city relations.

These findings consider the flows within networks that constitute London-Frankfurt relations. As boundaries give way to increasing interdependencies in a network society, co-operation between cities is found to be a priority for firms and institutions. We have introduced network thinking into consideration of London-Frankfurt relations. London and Frankfurt prosper by being within both similar and different webs of connections that have conditioned contemporary relations and whose dynamics will determine future relations.

Finally, we hope that this research has shown that, under conditions of contemporary globalisation, cities are at least as important as countries in trying to understand fundamental social change in the world today. Relations between cities cannot be 'enframed' as small versions of simple international relations. With globalisation, there has been the creation of a world city interlocking network that relates to, but exists separate from, traditional international relations and the comparative study of countries. 


\section{$1 \quad$ London and Frankfurt as world cities}

\subsection{Comparing London and Frankfurt}

This is a study of two cities under conditions of contemporary globalisation. Financially, globalisation operates through three time zones, and here we are concerned with two leading cities in the 'middle' time zone, Europe. The dominant city in this region is London. However, Frankfurt is generally perceived to be the up-and-coming financial centre in Europe, so much so that there have been suggestions that it might be 'catching up' with London or even poised to take over its leadership position. The location of the new European Central Bank (ECB) in Frankfurt and the launch of the euro with the UK, and therefore London, outside 'euroland' have fuelled such speculation. Here we use these events as a lever to investigate the relations between London and Frankfurt, to see whether these relations are changing, and to assess whether Frankfurt is indeed a serious rival to London.

By way of introduction we have prepared two tables that compare the two cities in terms of the latest available statistics. Unsurprisingly, both tables confirm the contemporary dominance of London. Table 1 provides some basic statistics and market figures. London leads on all ten criteria except one - Germany's current European leadership in the international bond market, most bonds being issued through Frankfurt. Otherwise the ratios of London's figures over Frankfurt's range from 11.6 for foreign equities turnover (Table 1(1)) to 2.25 for office space (Table 1(10)) and 1.4 for per capita GDP (Table 1(6)). Table 2 compares numbers of financial institutions, showing London well ahead of Frankfurt in six categories and Frankfurt in one. The latter reflects the success of foreign exchange which has been another source of speculation on the rise of Frankfurt. However, as can be seen from this table, this is the exception and not the rule, with London having strong leads everywhere else. There are three particular areas where Frankfurt is extremely weak for an international financial centre: investment banking, investment management and, above all, merchant banking. From the evidence of these tables it is clear that if there is a challenge from Frankfurt to London's position, at present it is only manifest in a couple of particular financial activities.

These simple comparisons between the two cities provide the necessary information to evaluate the cities' relative importance but they do not address the question of the relations between them. The latter question is vital once we understand that cities do not operate as separate 'islands' of activity - their raison d'être is their connections with other cities. London and Frankfurt are thus both part of the same network of cities that straddle the world providing financial and other services. It is through studying their different roles in this network, and how they relate to each other within the network, that we can make intelligent assessments of the changing relations between the cities and whether Frankfurt is becoming a threat to London's pre-eminence in Europe. This is the approach we take in this study: we investigate flows, linkages and connections between London and Frankfurt. In this chapter we provide the necessary background in three parts. First, 
Table 1

London/Frankfurt: key financial market and economic statistics

(1) Markets for foreign equities, $1999^{i}$

\begin{tabular}{lccccc}
\hline & $\begin{array}{c}\text { Turnover } \\
\text { (fbn) }\end{array}$ & $\begin{array}{c}\text { \% of } \\
\text { world } \\
\text { turnover }\end{array}$ & $\begin{array}{c}\text { No. of foreign } \\
\text { companies } \\
\text { listed }\end{array}$ & $\begin{array}{c}\text { \% of } \\
\text { listings }\end{array}$ & Global rank \\
\hline London & 1211 & 58.5 & 499 & 17 & 1 \\
Frankfurt & 104 & 5.0 & 195 & 6.9 & 4 \\
Totals & 2072 & 100 & 2833 & 100 & \\
\hline
\end{tabular}

(2) International bond market, 1999ii

(by nationality of issuer)

\begin{tabular}{lccc}
\hline & $\begin{array}{c}\text { Value } \\
\text { (\$bn) }\end{array}$ & \% share & $\begin{array}{c}\text { Global } \\
\text { rank }\end{array}$ \\
\hline Germany & 223 & 18.4 & 2 \\
UK & 116 & 9.5 & 3 \\
Total & 1215 & 100 & \\
\hline
\end{tabular}

(3) Market for fund management, 1999iii

(by institutional equity holdings, \$bn)

\begin{tabular}{lccc}
\hline City & Country & $\begin{array}{c}\text { Equity } \\
\text { holdings }\end{array}$ & $\begin{array}{c}\text { Global } \\
\text { rank }\end{array}$ \\
\hline London & UK & 2461 & 1 \\
Frankfurt & Germany & 310 & 13 \\
\hline
\end{tabular}

(4) Location of daily derivatives turnover (by institutional equity holdings, \$bn)

\begin{tabular}{lccc}
\hline & $\begin{array}{c}\text { OTC turnover, } \\
\text { April }\end{array}$ & $\begin{array}{c}\text { Annual number of } \\
\text { contracts (millions, in 2000) }\end{array}$ & Global rank \\
\hline UK & 171 & 223 & 1 \\
Germany & 34 & 454 & 5 \\
Totals & 474 & 3074 \\
\hline
\end{tabular}

(5) Foreign exchange dealing, 1998

(daily average) $)^{\mathrm{ii}}$

\begin{tabular}{lccc}
\hline & $\begin{array}{c}\text { Value } \\
\text { (\$bn) }\end{array}$ & \% share & $\begin{array}{c}\text { Global } \\
\text { rank }\end{array}$ \\
\hline UK & 637 & 32.2 & 1 \\
Germany & 94 & 7.0 & 5 \\
Totals & 1571 & 100 & \\
\hline
\end{tabular}

(7) The best European cities to locate a business, 1999v

\begin{tabular}{lc}
\hline City & Rank \\
\hline London & 1 \\
Frankfurt & 3 \\
\hline
\end{tabular}

(9) The location of Fortune Global 500 companies' European headquarters $(\mathbf{n}=390)^{\mathrm{vi}}$

\begin{tabular}{lccc}
\hline City & Number & \% of total & Rank \\
\hline London & 128 & 33 & 1 \\
Frankfurt & 12 & 3 & 5 \\
\hline
\end{tabular}

(6) GDP per head of selected EU regions (index $=100)^{\text {iv }}$

\begin{tabular}{lcc}
\hline City & & EU rank \\
\hline London (inner) & 229 & 1 \\
Frankfurt & 167 & 2 \\
\hline
\end{tabular}

(8) The best European cities in terms of tax policies, 1999v

\begin{tabular}{lcc}
\hline City & Score & Rank \\
\hline London & 0.70 & 2 \\
Frankfurt & 0.20 & 17 \\
\hline
\end{tabular}

(10) The best European cities in terms of office space $1999^{\text {vii }}$

\begin{tabular}{lcc}
\hline City & Weighted score & Rank \\
\hline London & 0.70 & 1 \\
Frankfurt & 0.31 & 5 \\
\hline
\end{tabular}

Sources: 'London Stock Exchange (quoted in International Financial Services London (ISFL) 2001); i'Bank for International Settlements (quoted in ISFL, 2001); iiiThomson Financial Investor Relations, Target Cities Report 2000 (quoted in IFSL 2001); ivEurostat (quoted in Healey \& Baker 2000); vHealey \& Baker (2000); viLondon First Centre (2000); vii'Healey \& Baker (1999). 
Table 2

The number of financial institutions in London and Frankfurt

\begin{tabular}{lccccccc}
\hline & $\begin{array}{c}\text { Futures/ } \\
\text { derivatives } \\
\text { companies }\end{array}$ & $\begin{array}{c}\text { FOREX/ } \\
\text { money } \\
\text { market } \\
\text { brokerage }\end{array}$ & $\begin{array}{c}\text { Investment } \\
\text { banks }\end{array}$ & $\begin{array}{c}\text { Investment } \\
\text { management } \\
\text { companies }\end{array}$ & $\begin{array}{c}\text { Merchant } \\
\text { banks }\end{array}$ & $\begin{array}{c}\text { Securities/ } \\
\text { brokerage } \\
\text { companies }\end{array}$ & $\begin{array}{c}\text { Foreign } \\
\text { banks }\end{array}$ \\
\hline London & 146 & 19 & 165 & 87 & 58 & 474 & $481^{*}$ \\
Frankfurt & 62 & 54 & 13 & 9 & 0 & 76 & $243^{* *}$ \\
\hline
\end{tabular}

Source: Seifert et al. (2000).

*as of March 2000 (source: IFSL, 2001)

**for 1998 (source: http://www.hit.de/us/hesloca/financ.htm, accessed 23 May 2001).

we set London-Frankfurt relations within the context of recent studies of 'world cities'. Second, we review the speculation on Frankfurt challenging London that built up a head of steam in the period up to the launch of the euro. Third, we describe the methodology we use to test this speculation and to take the argument further into the nature of London-Frankfurt relations. At the core of this report are the next three chapters that present three sets of findings. These deal respectively with the effect of the euro, the complexity of the relationship, and the networks involved.

\subsection{World cities as nodes in a world-wide network of cities}

The contemporary study of world cities can be traced back to John Friedmann's (1986; Friedmann and Wolff 1982) world city hypothesis of the 1980s. Drawing on research on global corporations (Cohen 1981) and their creation of a 'new international division of labour' (Fröbel et al. 1980), Friedmann posited a process of world city formation with corporate headquarters concentrated in a select group of cities. He viewed these as the 'command and control centres' of the world economy. This exciting new way of viewing the world was further developed by Saskia Sassen $(1991 ; 1994)$ in her identification of 'the global city'. Focusing on the top of Friedmann's world city hierarchy (specifically on London, New York and Tokyo), she highlighted the production of advanced producer services (e.g. in accountancy, advertising and law as well as financial services) in these major cities. Such business services are created from specialised professional information and knowledge that is only abundant in major cities. All business service firms that aspire to provide a 'seamless' service to their global clients have to locate offices in the main cities of countries and regions world-wide. Thus through their servicing of global capital, advanced producer services have created world cities as global service centres around the world. It is this feature of world cities as the location of knowledge-based, business services that is our subject matter here.

Running parallel to work on world/global cities, Howard Reed $(1981 ; 1989)$ was placing the study of international financial centres on to a sound quantitative basis. Through his construction of a hierarchy of international financial centres, this research is closely related to the world city studies. Obviously based upon a narrow specification of city functions, nevertheless financial services are important to all broader conceptions of 
world cities, including that of global service centres. Here we follow the convention of including banking and finance within the advanced producer services (see Dicken 1998, Chapter 12). Thus, we incorporate the international financial centre concept within our wider notion of world city.

The usual way of comparing world cities has been by ranking them using some measure of size such as number of headquarters. Such attribute measures have been employed in recent comparative studies of London and Frankfurt (and others): see Bindemann (1999), Dietl et al. (1999), Seifert et al. (2000), Häuser et al. (1990) and Harrschar-Ehrnborg (2001). As with Tables 1 and 2 above, such research provides valuable insights into the relative importance of cities but does not inform us about the relations between cities. The Globalization and World Cities (GaWC) Study Group and Network, wherein this study is located, specialises in research on inter-city relations. Looking beyond the study of world city formation, we are engaged in researching world city network formation. For this conception we focus upon Manuel Castells's (1996) 'space of flows' rather than the space of places, such as countries, that dominate thinking and research on comparing development across the world. We interpret world cities as the nodes in a world city network defined by the office networks of global service firms (Taylor 2001). Thus this particular 'Anglo-German' research is not the usual comparison between the two countries, but focuses instead on the relations between the most important nodes in the world city network within the UK and Germany, London and Frankfurt.

\subsection{London and Frankfurt in the world city network}

In the world city literature, London is always portrayed as a more important world city than Frankfurt. In a survey of major cities (top five listed) identified in 27 different studies, London appears 26 times, Frankfurt just 4 times (Beaverstock et al. 1999, Table 1, p. 447). And three of Frankfurt's four top listings are in studies of international financial centres. However, the two cities are more equal when all cities listed in a given study are counted: in 15 studies London is mentioned in all listings, Frankfurt in 13 (Beaverstock et al. 1999, Table 2, pp. 448-449). In the published roster of world cities based upon the most comprehensive set of data, both London and Frankfurt are allocated to the top rung as 'alpha' world cities: London shares pinnacle position with New York, Paris and Tokyo; and Frankfurt scores just below, level with Chicago, Hong Kong, Los Angeles, Milan and Singapore (Beaverstock et al. 1999, Table 7, p. 456).

In new research sponsored by the Economic and Social Research Council and running in tandem with this study, the world city network has been measured across 316 cities using the office networks of 100 global service firms (Taylor et al. 2001a). From this information the network connectivity of each city as a node in the world city network has been calculated by summing intra-firm linkages - for details, see Taylor (2001) and Taylor et al. (2001a). London is the most connected world city (through its global service firm offices), just ahead of New York. Frankfurt ranks 15th with 57\% of London's degree of connectivity. Putting this in a European context, Frankfurt ranks behind Paris, Milan, Madrid and Amsterdam but just ahead of Brussels. For this Anglo-German study a particularly relevant comparison is that between the two countries in terms of the profile of their national city network connectivities. In Table 3 the top ten cities from each country are listed, and the contrast could hardly be starker. Frankfurt has many national 
Table 3

Global service network connectivity for leading UK and German cities

\begin{tabular}{clcclr}
\hline UK & & \multicolumn{3}{c}{ Germany } \\
\hline Rank & City & Score* & Rank & City & Score $^{*}$ \\
\hline 1 & London & 1.00 & 13 & Frankfurt & 0.58 \\
101 & Manchester & 0.23 & 48 & Hamburg & 0.40 \\
106 & Birmingham & 0.22 & 49 & Munich & 0.40 \\
135 & Bristol & 0.18 & 50 & Düsseldorf & 0.39 \\
137 & Leeds & 0.18 & 51 & Berlin & 0.37 \\
138 & Glasgow & 0.18 & 74 & Stuttgart & 0.27 \\
145 & Edinburgh & 0.17 & 92 & Cologne & 0.25 \\
187 & Belfast & 0.14 & 158 & Dresden & 0.16 \\
191 & Nottingham & 0.13 & 162 & Leipzig & 0.16 \\
207 & Newcastle & 0.12 & 212 & Hanover & 0.11 \\
\hline
\end{tabular}

*Scores are proportions on the highest network connectivity (that of London).

world city rivals, London really has none: there are seven German cities ranked in the top 100 but only one UK city, London, at the top. This is important in considering relations between London and Frankfurt. We can assume the main UK base of all global service firms will be London, while the main German base will often but not always be in Frankfurt.

Finally, with these new measurements, we can compare cities for specific sectors. If we just consider the 23 of the $100 \mathrm{global}$ service firms that are in banking/finance, we get further initial insight into London-Frankfurt comparison as international financial centres. London has the highest financial network connectivity, but now Frankfurt rises to 7th position overall, just behind Paris but above Milan and Madrid. This rise in ranking is a feature of all the major German cities (compared to rankings in Table 3, Düsseldorf is 28th, Berlin 37th, Hamburg 45th, Munich 48th, Stuttgart 69th and Cologne 77th). In contrast, Manchester drops to 193th and the second UK city, in terms of financial network connectivity, is Edinburgh at 128th. Clearly the contrast between London and Frankfurt in terms of competitive national urban systems is accentuated in the financial sphere. To a large degree, German world cities are products of the success of the country's major banks, and it shows. However, when comparing the overall service firm profiles of cities, Frankfurt, with the other major German cities, appears as typically European in its emphasis, whereas London is very distinctive with no regional biases - that is, it is very global (Taylor et al. 2001b; see also Taylor and Hoyler 2000).

Thus from these new data we get a picture of London as a supreme 'all-rounder' world city with a global presence, and Frankfurt more as an international financial service centre with a largely European remit. These positions are wholly consistent with other assessments in the world city literature: for London's 'globalness', see King (1990), Sassen (1991), Kennedy (1991), Thrift (1994) and Llewelyn-Davies (1996); for Frankfurt's recent national and European repositioning, see Schamp (1999), Bördlein (1999), Grote (2000) and, for a long-term perspective, Holtfrerich (1999). But what neither the data nor this literature show is whether there are signs that Frankfurt is becoming a more encompassing world city with a global presence like London. 


\subsection{Enframing London-Frankfurt relations as competition}

Towards the end of the 1990s, the relationship between London and Frankfurt became a matter of widespread interest in the financial and business press. This was the result of three events that each signalled an increase in Frankfurt's status relative to London. First, the launch of the single currency with the UK on the outside, and the establishment of the ECB in Frankfurt. Second, the protracted negotiations for the merger of their stock exchanges, and their ultimate failure, have fuelled the idea that the relationship between London and Frankfurt is one of equivalence. Third, the success of Frankfurt's Deutsche Terminbörse DTB in eclipsing London's Liffe in the futures exchange market. All of a sudden London versus Frankfurt became a common story. Here we review articles from the London Financial Times (FT) and Frankfurter Allgemeine Zeitung (FAZ) to illustrate the enframing of the story of the London-Frankfurt relationship as a competitive one. This is the basic setting in which this research project was devised.

\subsubsection{Is Frankfurt 'catching up'?}

This is the question that dominates discussion of London-Frankfurt relations. The answers provided are somewhat ambiguous. While there is clear support for the idea that Frankfurt is becoming a serious rival to London, there are also many caveats due to the current differences in scales of operation we have documented earlier. We consider press responses to the three stimuli in turn.

From mid-1998, the financial press in the UK and Germany carried regular commentary on the likely effects of European Monetary Union (EMU) on the relationship between London and Frankfurt when the euro was introduced on 1 January 1999. The UK commentary highlighted the single currency and location of the ECB in Frankfurt as a major boost to Frankfurt's position against London and a serious concern from the London perspective.

In an article headlined 'Europe's single currency fuels Frankfurt's fortunes', the FT (13 April 1998) reported that 'Frankfurt's status as a financial centre is ... on the up' and went on to say: 'Already many foreign banks have begun to expand their operations in Frankfurt, mainly in investment banking, to take advantage of the changes taking place.' Hedging its bets, however, the article continued 'even so, Frankfurt's growth is overshadowed by that of London'. This ambivalence was repeated in a later article (FT, 24 May 1998) that dubbed Frankfurt 'Euroland's capital city' and asked: 'Will Britain's decision to stay out of the first wave enable Frankfurt to wrest leadership from London? Or is the City's dominance of European finance so well entrenched that being out on a limb makes no difference?' There was a possibility of major change because, 'being on the outside, London will not gain as much as it could ... There is, though, a small risk that things could turn out worse'. There were, however, other voices in the FT (3 July 1998) that told its readers: 'Don't be scared of the euro', referring to an 'oft-heard UK misconception about the euro ... that, if Britain does not join, Europe's financial centre will shift from London to Frankfurt'.

Comments in the German press were largely optimistic about the expected effects of the introduction of the euro, predicting a boost for Frankfurt as an international financial centre, although not necessarily at the expense of London. 
In an article entitled 'Der Finanzplatz Frankfurt wird vom Euro profitieren' (The financial centre of Frankfurt will profit from the euro), the FAZ (8 May 1998) reported that 'Frankfurt could reduce the lead of London', especially because of the UK not becoming part of EMU. However, London would probably reap the benefits from its position outside EMU. More to the point, the FAZ (23 May 1998) carried an article 'Der Euro mischt die Karten im Wettkampf der Börsen neu. BHF-Bank: Der Euribor bringt Wettbewerbsvorteile/Er soll die Vorherrschaft des Bankenplatzes London brechen' (The euro reshuffles competition between exchanges. BHF-Bank: The Euro Interbank Offered Rate brings competitive advantages/lt should end London's supremacy). And a little later there was a similar argument in an article (FAZ, 2 June 1998) with the headline 'Frankfurt rüstet sich für seine Rolle als Euro-Finanzplatz. Der Aufstieg zum internationalen Finanzplatz ist eng mit der Erfolgsgeschichte der D-Mark verknüpft'. (Frankfurt prepares for its role as financial centre of the euro. The rise [of Frankfurt] to an international financial centre is closely tied to the success story of the DM). It claimed that:

\begin{abstract}
Even the British are likely to become more open about the euro in a few years' time. The changing pro-European attitude of the banks in the City might play an important role. It is likely that after the introduction of the euro continental exchanges and banks will be able to attract a substantial part of international financial business to the continent.
\end{abstract}

However, the conclusion was that, despite all the recent success of Frankfurt, London's leading role as most important European financial centre is not in danger. The most explicit booster article for Frankfurt in the FAZ (19 October 1998), under the heading 'Frankfurt wird führender Investitionsstandort' (Frankfurt becomes leading location for investment), reported: 'For the first time European top managers see Frankfurt as leading location for investment in the future and London - because of Great Britain being outside of EMU - as loser in the competition for investments and jobs.'

The introduction of the euro has been fundamental to the concept of the single European market, but the efficient operation of the market requires standardisation of trading and settlement infrastructures across Europe (see, for example, Laulajainen 2001). While there has been widespread acknowledgement of the need for co-operation in the cross-border integration of systems and practices, the relations between financial institutions in London and Frankfurt have been represented ambiguously, reflecting their position as market competitors in a large press coverage.

The front page of the $F T$ (17 September 1997) carried an article headlined 'Link-up threat to Liffe's supremacy: Futures exchanges join forces to challenge London', describing the joining of the three largest futures and options exchanges in continental Europe as a direct challenge to London's dominance of the business. Later (FT, 24 May 1998) it was reported that: 'Eventually, Frankfurt could have a hinterland to rival London's. ... Being home to the European Central Bank will be an advantage ... The same goes for the current battle between Frankfurt's DTB and London's Liffe'.

The proposed alliance between the Frankfurt and London stock exchanges was reported ambivalently in both London and Frankfurt. The potential problems were rehearsed in the $F T$ (7 July 1998):

London's stock market capitalisation is double that of Frankfurt and it is the main European financial centre at present. That might make London seem like the obvious 
choice to act as senior partner. But will the other members of the new market want to see it run from outside the Emu zone?

In contrast, the FAZ (28 April 2000) rated the merger between the Frankfurt and London stock exchanges as the pinnacle so far of the rise of Frankfurt as a financial centre, although later (FAZ, 4 May 2000) some doubts were expressed.

\subsubsection{Competition or co-operation?}

Just by asking whether Frankfurt is catching up, the reporting of relations between the two cities is enframed as a competition. There is a mindset that has become embedded in the story of recent London-Frankfurt relations that depicts the cities as rivals. It seems that the metaphor for describing these inter-city relations is the world of international relations. But this is not the only way of looking at relations between cities. In our discussions above we introduced London and Frankfurt as part of a world city network. This implies a very different story. Relationships between members of a network are complementary in nature. Therefore, we need to consider the mutuality between London and Frankfurt in the world economy at least as much as their famous rivalry.

There are, of course, intimations of mutuality rather than competition in some reporting. For example, an article in the FT (24 May 1998) suggests that 'both London and Frankfurt will benefit' through the creation of a single European capital market. Under the headline 'City "vital to EU financial sector"', the FT (17 June 1998) reports the findings of the Centre for Business Economics and Business Research, and quotes the view of Judith Mayhew, Chairman of the Corporation of London's Policy and Resources Committee:

It is a misconception to see London as being in competition with the rest of Europe on the contrary, the whole of Europe benefits from the vigour and diversity of London's international financial services industry. If you damage London you damage Europe.

However, these are very much the exceptions. The international relations metaphor dominates and is most clearly reflected in the language used.

If the last point is doubted, here are some examples of the language used, which seems quite remarkable when removed from its immediate context. As well as the relatively mild 'challenge' to London (FT, 17 September 1997) and 'threat' to Frankfurt (FAZ, 4 May 2000), and their depiction as 'fierce competitors' (FT, 11 July 2000), there is talk of 'a bitter war for supremacy' (FT, 10 July 1998), and 'a battle between London and Frankfurt' (FT, 7 July 1998). It seems that, with Paris, London and Frankfurt are 'fully engaged in [a] battle right now' (FT, 9 March 2000); London has 'lost the contest' and suffered a 'defeat' that is 'a symbolic blow for the City' which is, nevertheless still 'fighting' (FT, 31 May 1999) against Frankfurt's 'powerplay' (FAZ, 19 March 1999). Anybody reading these phrases without mention of the cities would assume we were discussing relations between countries in the middle of a major war! There is no doubt that international relations metaphor is a powerful one, but we must always remember that we are dealing with inter-city relations and cities operating through networks. At this stage we do not have to choose between our network model and the international relations metaphor, we search for both competition and co-operation in this research. 


\subsection{Methodology: studying inter-city relations}

The quantitative analysis reported earlier provides background material for considering the competition between London and Frankfurt but it cannot begin to uncover the processes involved. These mechanisms can only be explored through careful study of the actual behaviours and attitudes of the key persons within the institutions and advanced producer service firms doing business in London and Frankfurt. This requires a completely different methodology, a qualitative approach involving key players involved in the intercity relations. Thus in-depth interviews were carried out with important personnel in financial and business service firms in London and Frankfurt and with some institutional representatives in both cities.

In London 10 banks and 15 other non-banking producer service firms were interviewed (see Appendix 1). In Frankfurt 9 banks and 14 other non-banking producer services were interviewed. Most firms interviewed ranked in the European top ten of their respective service sectors. Of the non-banking producer services interviewed in both cities, the research collected data from those sectors allied closely to the financial industry: law, accountancy, management consultancy and advertising. The interviews took place over two specific time census periods. Census one, using face-to-face taped one-hour interviews, evaluated changing Frankfurt-London relations one year after the launch of the euro. Census two, using 30-minute in-depth telephone interviews, evaluated changing Frankfurt-London relations up to two years after the launch of the euro. Each face-to-face and telephone interview took place with a senior member of the firm, at the grade of partner and/or vice-president and above, who had responsibility for the firm's adjustment to the euro with respect to Frankfurt-London inter-city relations (Appendix 2). The questions raised in both these interview census periods focused on three major themes pre and post euro: Frankfurt catching up with London; changing business relations in Frankfurt and London; and sectoral (e.g. banking, law) responses in London and Frankfurt (Appendix 3).

The interviews with regulators, professional bodies and state agencies were interactive in nature. Summaries of findings from the first interview census period were provided as the basis of face-to-face interviews with a selection of key state, financial and sectoral bodies which represented both Frankfurt and London's interests in the euro. Eighteen institutions were interviewed in London and eight in Frankfurt (Appendix 4), and questions focused on sectoral responses to the euro in a London-Frankfurt context (Appendix 5).

In the next three chapters we present the results obtained from this methodology. We have carefully trawled through hours of recorded opinion to put together an overview of the positions of key players in London and Frankfurt This has involved finding consensus where it exists and delineating, and giving due weight to, different positions on London-Frankfurt relations. This exercise has been carried out in conjunction with our knowledge of the world cities literature to create a nuanced structure for the 'collective' views of practitioners in the two cities. 


\section{The effects of the euro on business relations between London and Frankfurt}

\subsection{Contrary findings}

As we have seen, most prior commentary on the effect of the new currency and its management on London-Frankfurt relations assumed that it heralded rivalry between the two cities for leadership in Europe. This has not been found to be so.

Three major findings stand out from the parts of the interviews that focused on the effects of the euro on London-Frankfurt business relations:

- The new currency has had no wholesale effects on changing business relations between the two cities.

- $\quad$ Frankfurt's position in Europe is strengthening, but not at the expense of London.

- London remains the main European financial centre.

Despite the fact that the euro has only recently been launched, these findings are so strongly evident in our interviews that we can dismiss the idea that the euro will have an appreciable influence on London-Frankfurt relations in the near future.

\section{2 'The currency is not an issue"}

One Frankfurt interviewee commented: 'The fact that the euro has not been introduced in England has changed nothing in relation to the leading position of London, including the euro-business.'.

Respondents interviewed in both cities during the first census period consistently reported that the euro had not affected their business relations between London and Frankfurt. Equally, the major view was that London had not suffered any disadvantage from being outside the 'euro-zone'. However, a minority of respondents in London-based German and UK firms warned that the euro was already having, or could have, effects for their clients in professional services. This issue was discussed primarily in relation to UK exchange rate instability. It was not, however, perceived as a problem for the City of London.

Representatives of firms with the most global business outlook in each sector typically dismissed the euro issue as irrelevant to business location as 'there is free capital mobility', business is 'conducted on a global basis' and 'the market is being virtualised'. The euro 
was generally dismissed as a 'back-office issue'. Equally, those firms with a strong European focus generally emphasised that decisions on where to locate an operation 'are not made on the basis of a currency', but that location is decided on the basis of 'business locally or internationally'.

During the second census period, telephone interviews strongly reinforced the face-toface interview findings. Typical responses on the issue of the euro included:

It's not making any difference at all.

It's having no effect on business strategy.

I still think it makes no difference - it's not a huge issue.

No, it's not an issue for us.

It's still not having a major influence.

There's been no impact on business in London and Frankfurt.

Some euro concerns were raised. For example, two London-based firms' respondents were concerned about being excluded from political decision-making in Europe in the long term. Equally, a London-based respondent from the non-banking sector thought that if the UK goes in, 'the major effect will be on the British banks ... [who] ... will be weak on the continent and that will affect the merger situation'. One highly globalised firm with a European headquarters in London expressed concern that 'London is more expensive' and, in the context of US economic recession, that this was affecting the movement of staff between offices internationally, although that this was 'not so important as to impact on strategic business decisions'.

However, the general outlook of respondents in both Frankfurt and London was positive for both cities irrespective of whether the UK joins EMU. Two London-based firms commented: 'We're doing a lot of euro-business out of London' and ' $60 \%$ of our income is in Europe already ... currency doesn't matter'. London office involvement in euro preparations was reported in the British banking sector, and some London-based offices in accountancy and management consulting commented on some increase in interest in the euro on the part of clients. 'occasionally we see a direct client interest in the issue of the euro', but there are no effects 'other than potentially more business coming'. One London commentator expressed the view that 'Eddie George is still confident about London's ability to hang on to its business and he has been proved right'.

\subsection{Frankfurt's position in Europe}

Responses obtained from interviews undertaken during both census periods overwhelmingly reported that Frankfurt's position as a financial service centre is strengthening relatively, but that the changes are not as strong as expected, and that there is no threat whatsoever to London's financial hegemony at this point in time. 
Frankfurt-based respondents focused on 'Europeanisation' and 'continental European capital' (that is, demanding firms to switch from national to European regional markets and business models), political changes, economic policies and 'changes in the atmosphere', including 'a very optimistic phase in Frankfurt'. For some firms this has been associated with a shift to a more international outlook and knowledge transfer. Changes in business in Frankfurt were seen as concerned not only with Europe, but also with firms' wider relations internationally: 'The important thing is that there is growth ... but I don't think that's because of the euro or the European Central Bank'.

Most Frankfurt-based respondents did not believe that London not belonging to the euro-zone and the location of the ECB had made a difference to Frankfurt's position as a financial centre. Typical Frankfurt responses were:

It's an illusory argument.

There hasn't been a rush to Frankfurt since the introduction of the euro.

Almost nothing has changed because of the euro.

Boundaries are overcome easier.

Scale was seen as critical to European market change by respondents based in London and Frankfurt: 'The euro is a symptom of underlying change rather than a cause or facilitator of change, change that was going to happen anyway'. London-based respondents emphasised the potential, expansion and growing importance of capital markets in Germany for their cross-border business operations together with increasing client demand for cross-border professional services. German industry was seen to have 'been sleeping'. The need to forge relationships in Germany and the importance of 'e-business' as a vehicle for cross-border business were strongly emphasised. In Frankfurt and London, German unification and developments in the German services' markets were discussed as important stimuli to changes in Germany: 'The opening up of old economic and social structures' that were necessary 'to become competitive or lose out very badly in globalisation'.

Respondents in London and Frankfurt believed that Frankfurt is moving towards greater innovation, deregulation, liberalisation and integration of markets, and is capturing parts of the financial services market:

They have been relatively smart and quick off their feet in the context of some specific developments around market infrastructure.

The Neuer Markt was an attractive coup.

Frankfurt can now claim to be quite a significant player in the securities' market, whereas it certainly wasn't before.

Again the changes were not seen to have been caused by the euro. The significance of European attempts to ensure that financial markets become more integrated was frequently emphasised: 'That is more important than anything to do with currency'.

London's role as the focus for European activities, for example, of American banks and lack of skills in Frankfurt were also raised by some respondents in both cities as more 
important to contemporary relations between the two cities than issues of the euro and the location of the ECB. A London-based respondent said that: 'More and more people who are capital-raising in the world come back to London or to New York'. A Frankfurt respondent expressed the view that 'If the euro was introduced in London, this could have positive effects for London, but these would be added on top'.

Some respondents in both cities noted a strengthening of German influence because of the strength of its economy, and this was discussed in relation to possible isolationism of the UK outside EMU. The issue of further financial integration and harmonisation of standards and practices was seen as key for business in both cities, how to get liquidity in stocks around Europe, low cost switch clearing and netting, to facilitate cross-border business. The achievement of progress was widely regarded as needing a 'European approach' which one respondent saw as coming from a 'multi-city fusion'.

These results indicate that the reasons for shifting cross-border financial flows are multicausal and that the UK position outside EMU is not a barrier to flows in both directions between London and Frankfurt. Nevertheless, if the UK did join EMU this could enhance relations and flows between the two cities to the benefit of both.

\subsection{London remains the premier European financial centre}

Interviews in both census periods and both cities confirmed that Frankfurt was not seen as a serious contender to London as a global financial centre. Frankfurt was generally perceived to be very strong and gaining relative to London because of its position in a strong German economy. As expected, Frankfurt-based respondents were generally more optimistic about Frankfurt's prospects as a major European financial centre, but the gap between the two cities was perceived to be wide on both sides. London-based respondents generally stressed Frankfurt's position as being firmly in the 'second league', 'catching up, no, making progress, but from a low base'. Frankfurt-based respondents consistently emphasised the 'big gap' between the cities and most did not see the position changing substantially.

European growth was seen to be benefiting both cities. Service sector firms were said to be expanding in Frankfurt, but the increasing strength of Frankfurt was seen as 'feeding into London, not draining away from it'. Some London-based accountancy firms noted an increasing number of clients wanting to be listed in Frankfurt, particularly in newer hightechnology businesses, but there were also an increasing number of German businesses wanting to invest in London. The stock exchange merger was generally seen as an opportunity for both cities that could give Frankfurt and London a big advantage 'because everything would be a much, much bigger cake and less costs because settlements and all these things would be brought to the same standards'. These results suggest that both cities can gain from co-operative relations.

Many responses reflected an awareness of Frankfurt as a city in competition with London: 'Frankfurt is growing and attempting to take some business away from London'. Respondents in both cities believed that: 'People take the possibility of doing business in Frankfurt more seriously than they would have done before.' But the overwhelming view was that London remains highly favoured as a place to do business over Frankfurt. As 
evidence of this, key foreign banks were believed to have continued to increase their representation in London in terms of staffing levels: Deutsche Bank, BNP Paribas and Westdeutsche Landesbank were given as examples. Subsequent telephone interviews with the same respondents conducted in spring 2001 revealed that the European banks interviewed had not cut back their London staffing levels and some had increased them. London was generally regarded as still being 'the premier European financial centre on most measures that you want to use'.

Scale and infrastructure were frequently discussed by respondents in both cities as reasons for London's ongoing strength - 'a financial trading centre for the world' - relative to Frankfurt. London-based respondents in German and European firms typically saw London as 'the only city in Europe to do true international business'. Business in Frankfurt, and in Germany generally was widely regarded by them as 'still domestic business'. London was discussed as a satellite to their European-centred operations and used 'to do business back into continental Europe'. There was felt to be much business around and their London operations were seen as 'adding resources and not taking them out of London'. While continental business is growing and of great importance to European firms, the fact that not all firms are centred in Frankfurt, due to Germany's decentralised structure, was widely regarded as a disadvantage for Frankfurt by respondents in both London and Frankfurt.

Many London-based respondents perceived Frankfurt as remaining over-regulated, with inflexible employment structures, an undeveloped skills base and high social costs compared to London. However, respondents in both cities saw Frankfurt as making rapid progress in developing as a financial centre. Increasing liberalisation and innovation in Frankfurt were noted, and some respondents in both cities believed Frankfurt to be cheaper to do business in than London. However, German firms' respondents based in London strongly emphasised the advantages of London over Frankfurt as a place to do business. London was regarded as having, 'the skills ... the mindset ... the flexibility and ... the creativity that is very much in demand ... that's the culture on which London flourishes'. One German firm had mapped the unique selling points of London, which included low regulations, the mentality of people and the acceptance of leadership. Reasons for locating in London included product development and the flow of skills back to Frankfurt and employment flexibility: 'London is absolutely superior to Frankfurt on employment ... it is ability on the way in as well as on the way out that is an infrastructural advantage for London as compared with anywhere else in Europe'.

American financiers and industrialists were widely perceived 'to feel more comfortable working in and through London' and 'to have very clearly favoured London' relative to Frankfurt. American perceptions, particularly those of the US investment banks 'dominating banks in the dominating world economy' - were generally regarded as critical to the maintenance of London as a global centre. The fact that London is Englishspeaking was seen widely as a key factor in the American choice of London as a European centre. A number of respondents commented on their personal knowledge of American views: 'They say all this stuff about Frankfurt versus London is just bull because the reality [is that] London works already, that's what the banks tell me'. Most respondents believed it difficult to see the status quo being dislodged unless there is a significant change in the American perception of the market-friendliness of the two cities, 'the Anglo-Saxon model versus the European model'. 
London respondents referred to the City of London as having 'a kudos which is global', being 'a hallowed sphere' and 'a virtual reality', 'outside the real economy' and 'a honey

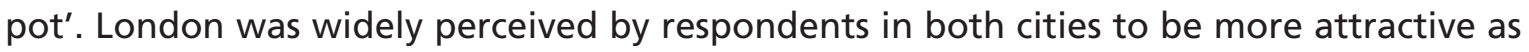
a living place for skilled employees of all nationalities. However, whereas Frankfurt was frequently condemned as a dull living environment by London-based respondents of all nationalities, 'the restraint is no one wants to work in Frankfurt'. Frankfurt-based respondents generally expressed more positive feelings about their personal experience of living and working there.

Some threads of doubt expressed by respondents were that people 'are hedging their bets', waiting to decide where to increase resources, that London would maintain it's position 'as long as banks and the financial communities aren't under pressure', and some European respondents believed that it will only be when the market contracts that decisions will have to be made whether to shrink operations in Frankfurt or London. The comments of two respondents in highly globalised firms with European headquarters in London are significant:

It's just simply the result of the fact that if you want to see your counterpart he's sitting here somewhere and it's why we're sitting here.

As long as banks and the financial communities don't have that kind of cost pressure at all [relative costs of doing business between Frankfurt and London] this doesn't matter, but should that ever change it will matter.

\subsection{The need to study complexity}

Research findings suggested that the introduction of the euro and the location of the ECB have not had a significant influence on business relations between service firms in London and Frankfurt. Frankfurt has not grown at the expense of London. London has not experienced leakage of financial services or market share to Frankfurt. But, the research findings have highlighted the overwhelming complexity of London-Frankfurt changing relations. It is no surprise to find that the introduction of the euro has not resulted in wholesale financial service reconfiguration in the EU. The political decision to locate the ECB in Frankfurt, in tandem with the introduction of the euro, quite simply will not undermine London's global financial status. London's financial centre has a deeply embedded matrix of firms, players, institutions and cultural practices which are tightly spatialised in well-established knowledge networks and discourses. As we shall see in the following chapter, firms play an important role in the reproduction of the complexity of London's changing business relations with Frankfurt, pre and post euro. 


\section{The complexity of London-Frankfurt relations}

\section{1 'The trouble is it's a huge jigsaw'}

The reason why the euro and ECB have had minimal effects on business relations between London and Frankfurt is that inter-city relations do not operate as a simple cause-effect mechanism. Relations between major cities are highly complex affairs and should not be viewed as a primitive competition with one city attempting to knock the other off top spot. As one of our respondents put it: 'The trouble is it's a huge jigsaw'. In this chapter we attempt to put this jigsaw together as a world city network and to understand the London-Frankfurt link within that larger whole.

We interpret the world city network as an interlocking type of network created by financial and business service firms through their location policies for offices (Taylor 2001). In their global strategies, firms have to decide where they need to have offices in order to provide the seamless service clients demand for cross-border business. In this way certain key cities have become the 'places to be' in order to service particular sub-markets, national and regional, within an integrated world market. It is these cities that have become world cities, nodes in the world city network. Thus world cities are 'interlocked' one into another through the office networks of service firms. The result is a world city network as the amalgam of offices each receiving and dispensing flows of information and knowledge within and between cities.

The key point that arises from viewing world cities in this way is that, as part of an interlocking network, the key agents in the production and reproduction of the network are the firms and not the cities themselves. Hence the increasing importance of cities under conditions of contemporary globalisation is not due primarily to the promotional activities of city governments. To understand how a particular city is faring, its links to other cities through business firms are the crucial determinant of success. It follows that city competition may be less important than city synergy or mutual reinforcement of cities by cities in the ongoing reproduction of the network by firms. This is consistent with Krugman's (1994) argument that it is only firms that compete in the world market and not nations or, by extension, cities (Taylor 2001).

This chapter is organised into three sections in a way that is entirely compatible with Krugman's position. We begin with the firms and how our respondents describe their behaviour in operating in London and Frankfurt. Within their sectors the firms are engaged in competition in world markets for knowledge products. This competition brings forth highly complex issues facing participants in such rapidly changing global markets. This is the root of the complexity in London-Frankfurt relations. We conceptualise it as a series of tensions within the sector markets that each firm has to manage in order to operate successfully. We identify one underlying tension in Section 3.2 and then a series of specific tensions in Section 3.3. The outcome in terms of the nature of the business relations between London and Frankfurt is the subject of Section 3.4. 
These sections describe the major findings on the complexity of London-Frankfurt business relations:

- The fundamental tension facing firms in both London and Frankfurt is negotiating trans-border (global) reach against local sensibilities.

- There are other critical tensions in organisation, knowledge production, operationalisation and locational issues.

- The primary inter-city outcome of this inter-firm competition is a co-operative relation between London and Frankfurt within a wider network.

\title{
3.2 The underlying tension: global versus local
}

The global-local dichotomy was the underlying tension for all sectors in their London-Frankfurt relationships. The increasing need to respond to 'globalisation' was the pre-requisite to successfully doing business in the local contexts of London and Frankfurt. However, great diversity of global-local organisational and business relations was found to exist within and between the service sectors studied. Organisations responded differently to the challenges of globalisation; however, it is possible to identify some key characteristics for each sector which have shaped business relations between London and Frankfurt.

\subsubsection{The banking sector}

Banks varied most in terms of the degree to which organisations had a global perspective and local operation. Only the very largest investment banks could be said to have a truly global perspective in relation to markets and business strategy. Most of the banks interviewed in both cities were dominant players in a European or domestic market, although all spoke of some increasingly 'international' ambitions. Business operations in banking were more often discussed in relation to specialised local, regional and global geographic scales. As one London-based UK banker commented:

\begin{abstract}
lending to local corporates is a local business ... so you can be a local player indefinitely so long as you only seek to do local things. What you can't do is participate in regional scale businesses or global scale businesses on a local scale and be viable.
\end{abstract}

The regionalisation of financial markets in Europe was seen as a key driver for crossborder European market participation and organisational capacity, but also for an increasing need to be localised. A London-based German banker commented:

\footnotetext{
Increasingly you have to put your resources on to the ground because you want to be close to the customer. So you get a shift on the sales or origination side rather than the production side because the production 'kitchen' can still keep one centre and supply a large geographic area, probably the whole of this time zone.
}

Relations between business in London and Frankfurt consistently reflected the specialist role of London as a centre for 'international' financial business and Frankfurt as a 'local' base for European and German domestic business. Continental Europeans 'have absolutely no alternative other than to run two big operations at the same time', according to German banker based in London, yet not all German banks are 
headquartered in Frankfurt. As to non-German banks, respondents generally spoke of a much smaller presence in Frankfurt than in London that could be adjusted flexibly according to changing market requirements, and of e-commerce as a key vehicle for development of cross-border ability.

\subsubsection{Advertising}

The respondents spoke of advertising as a product that crosses borders more easily than those of other service industries, but localisation (niche marketing) was vital to appeal to different cultural sensitivities. As an advertising executive based in London commented: 'If you took our advertising in the UK or Germany, it's still the same car or it's still the same media, so it's the cultural difference which you have to understand'. While London is the European headquarters for most agencies and is widely regarded as a global creative centre of excellence, business in both London and Frankfurt was generally perceived as localised activity within a global network. Thriving business in both cities was seen as beneficial for all parts of the network. Regardless of differences in agency nationality, management styles and the degree to which the networks are locally integrated and embedded into local cultures, specific business relationships between the two cities were generally seen by those interviewed as an irrelevance. For one agency, the firms in London and Frankfurt 'are independent companies and both report into the European headquarters ... they have the same functions, the same set-up, the only difference is that the London office houses the European headquarters'. However, whereas London is clearly the major advertising centre for the UK market, Frankfurt was regarded as one of five main advertising centres in Germany, the others being Düsseldorf, Hamburg, Munich and Berlin.

\subsubsection{Accountancy and management consultancy}

While most accountancy and consulting firms interviewed have a long tradition of international operations, markets were generally perceived as having remained predominantly local. However, current and predicted growth of the European market was generally regarded as producing a shift of business relations between London and Europe, with London-Frankfurt relations centring principally around the financial services market and the new economy. The importance of the German market and the latent demand for accounting and consulting services in Germany are seen to be leading to increased business interest in Frankfurt and increasing business flows between London and Frankfurt.

Within the network brands, national UK and German firms were generally seen as having remained important. There is a variety of organisational structures amongst the firms interviewed (e.g. partnerships, franchises). Some networks have recently introduced greater sharing of economics to deal more easily with cross-border business. The maxim 'Think global, act local' was cited as typifying the organisational relations of one very large international accountancy and consulting firm. The legacy of national differences in business and professional practices and regulations was emphasised in both London and Frankfurt. Business relations between the two were generally discussed in terms of a transfer of Anglo-Saxon practice and skills, through London, to continental Europe where these are now needed. 


\subsubsection{Legal services}

London-based respondents saw the process of globalisation as a 'pull' process, driven by client demand where increasingly global reach was necessary to market survival. The need to keep up with competitors was seen as a 'push' factor. All major UK law firms were said to be increasingly required to engage in international work. Despite the dominance of English and American law internationally, most major London law firms were currently highly focused on developing regional European business relations to service increasing demand for cross-border legal services.

Relations between law firms in London and Frankfurt were generally perceived to be framed by: the London-based business need for local depth and strength in Germany to access the German market as well as service international cross-border clients; and the need within Frankfurt for access to London-based international and English law expertise to meet the requirements of a changing German legal market. In the wake of a spate of mergers and strategic alliances between English and German partnerships, evolving London-Frankfurt business relations were represented by respondents in both cities as reflecting strong national cultural differences in professional and business services including systems of remuneration, decision-making, profitability and a change from a German service-based to an Anglo-Saxon transaction-based business model. Despite these differences, the development of legal services relations between the UK and Germany was widely perceived to be important for business expansion in both countries. While this was seen to be increasing legal business relationships between London and Frankfurt, the latter city, unlike the former, Frankfurt was regarded as one of several centres for legal services in Germany, albeit by far the most important for corporate legal work.

\subsection{Specific tensions in inter-firm competition}

Four specific tensions produced the local-global interdependencies and underlie the production of relations between London and Frankfurt.

\begin{tabular}{l|ll}
\hline Tension & Global pressures & Local pressures \\
\hline Organisational & Consolidation & Disaggregation \\
Knowledge & Specialisation & Diversification \\
Operational & Centralisation & Decentralisation \\
Locational & Concentration & Dispersion \\
\hline
\end{tabular}

\subsubsection{Organisational tension: consolidation versus disaggregation}

\section{The need for consolidation}

The size of global and regional markets was seen by respondents as driving increasing organisational scale. Functional diversification and new technology demands were seen as requiring size in the market that can be most readily achieved through mergers and alliances (M\&A) and the formation of strategic partnerships. For example, changes in the management consulting sector to both commodity- and relationships-focused business require scale, and this tendency will apply to firms operating in London and Frankfurt: 'You can only be successful in both if you have a critical size, that's the reason why the restructuring process will continue', as one London-based respondent put it. Law and 
banking firms interviewed emphasised the need for consolidation to finance the investment in information technology (IT) necessary for cross-border activity. Mergers and alliances were regarded as well developed in investment banking where critical mass is regarded as essential to profitability.

The achievement of increased consolidation in the market was discussed as a specific objective by firms involved in cross-border M\&A and strategic alliances between London and Frankfurt, suggesting that this driver also contributes to the development of intercity service sector relations.

The principal interests of London-based firms interviewed in Frankfurt are the size of the German market, the latent demand for services and the development of new capital markets that can contribute to value-building growth. At the same time, market fragmentation provides scope for rationalisation and economies of scale through consolidation to compete in the global marketplace.

The largest accountancy and consulting firms had consolidated globally to the extent that, in the context of current regulatory issues, the potential for further consolidation was regarded as limited and firms are looking to the European and German markets for revenue growth. In legal services the situation is different, with scope for national and cross-border Anglo-German consolidation in a highly dispersed market - although national cultural differences have led some English and German law firms to stop short of full merger, preferring strategic alliances as a means of achieving cross-border valuebuilding growth. In both sectors, these drivers were seen to be causing a strong increase in business flows between London and Frankfurt.

In advertising, the sector was seen as having substantially internationalised in recent years within three major global groups. London is widely regarded as the dominant creative centre for Europe, while Frankfurt is not generally perceived as a key creative centre within Germany. However, Germany is seen as a bigger advertising market than the UK and it is important to the holding companies and agency networks that both London and Frankfurt are successful within their own markets. Nevertheless, direct business relations between London and Frankfurt were perceived as relatively weak, with Frankfurt business being focused on a local market within a global network.

In banking, consolidation has hitherto been regarded as a largely national activity in retail business, due to national regulatory, tax and industry differences and a perceived lack of scope for cost savings and revenue enhancement through UK-German mergers. Regulators' 'national pride' in the UK and Germany was regarded by some respondents as a barrier to cross-border consolidation. In general, UK consolidation is regarded as having almost reached 'end game' due to competition issues, whereas Germany is perceived as having great scope to improve margins through consolidation of its 2900 banks. Cross-industry mergers, for example in banking and insurance, were seen by some respondents as potentially presenting opportunities for further consolidation across the financial services sector.

Service industry consolidation can be seen to impact on London-Frankfurt relations in diverse ways for specific sectors. For example, the space of inter-city flows between London and Frankfurt for advertising would seem to be less 'thick' than for law due to the highly globalised and localised structure of advertising networks. In general, firms with organisational structures that facilitate and promote collaboration and co-operation 
between London and Frankfurt saw resultant increased inter-city flows as generating added value. However, London, as the European headquarters for much international service business, would seem to benefit additionally from dominant flows passing through a wider space between local regional operating centres and global headquarters.

\section{The need for disaggregation}

At the same time, other demands were seen as driving the break-up of large organisations. Speed, flexibility and agility were regarded as necessary to remain competitive, yet increased scale was also associated with loss of flexibility. Relatively smaller-scale accountancy and consulting firms in our survey emphasised the value of their greater agility in comparison with that of larger organisations. Their size was said to enable them to respond to changes in the market more rapidly and easily.

The future demerging of large firms was seen by some as allowing service specialisation and focus on core functions that add value. While this in itself would not necessarily change the balance of flows between London and Frankfurt, associated trends could. Operational cost-efficiencies (lower labour and property operating costs) associated with outsourcing and contracting out of peripheral functions, facilitated by information and communication technology (ICT), were discussed by some respondents as potentially leading to the future vertical break-up of traditional organisational structures across the service industries. These developments could have fundamental implications for the nature of service firms and employment, with consequences for business in both London and Frankfurt. One non-European banking respondent based in a London European HQ saw the changes as 'challenging the whole concept of what a firm is. What is it then? Is it purely a loose legal aggregation of individuals or is it something a bit more than that?'

It was generally thought that medium-size firms would lose out in the process of change to both increased organisational scale and disaggregation. A legal services commentator based in London expressed a view that was common across all sectors:

Not all of us [firms] are going to be in this position in another five years' time - there'll be a drop-out ... some will be global firms and ... you'll have key niche players ... some of them are going to move off the map and be merged into other things.

Some respondents, typically in advertising, banking and law, saw national and local cultural differences between the UK and Germany as a constraint to cross-border integration of business operations between London and Frankfurt. Some British and German lawyers believed that this could act as a driver for the demerging of recently merged legal entities.

The pressures for increasing industry representation at the top end of the services sectors and at the bottom 'niche' market end, are likely to drive continuing restructuring of business relations between London and Frankfurt. While organisational disaggregation was thought by some respondents to have future implications for cities generally as centres of service employment, it seems unlikely that geographic disaggregation will be adopted for all services' functions. 


\subsubsection{Knowledge tension: specialisation versus diversification}

\section{The need for functional specialisation}

The structural shift to a knowledge economy was seen to emphasise the importance of people not just as customers but as skilled employees in all services business. Specialisation was seen as a key concept in contemporary service production. Maintaining competitiveness in a globalising market was said to require firms to re-evaluate and concentrate on their core competencies, redefine the markets they want to serve and decide between a range of business models. This has led one continental European bank to increase its investment banking concentration in London and Paris but also to focus this activity within Germany in Frankfurt at the expense of other German centres.

In accountancy and consulting services, specialist skills now need to be available anywhere in the world but cost constraints were seen to necessitate functional specialisation within global service distribution networks. ICT and improved international travel mean that specialist skills do not need to be physically located everywhere. For one international accountancy firm interviewed, for example, this means developing and transferring corporate finance and M\&A skills from London to Frankfurt to meet growing German market demand and, at the same time, increasing deployment of international teams drawing on specialist expertise from anywhere in the global network.

Functional specialisation can therefore be seen as encouraging a flow of skills and AngloSaxon business culture from London to Frankfurt within service firm networks. While it is widely thought that this must logically eventually diminish London's comparative skills advantage over Frankfurt, because skills, knowledge systems and intellectual capital are increasingly managed and mobilised across networks, in general it was felt that the critical mass of skills would remain concentrated in London.

\section{The need for functional diversification}

In intensely competitive cross-border markets, the largest firms were seen to be seeking to differentiate their services to enter new parts of the market. In financial services, for example, some firms have developed their market share by specialising in particular market areas, such as M\&A. In the accountancy and consultancy sectors, firms were perceived to be actively diversifying their business models in order to achieve differentiation from competitors.

In a context of increasing demand for cross-border services, in both cities the major constraint to growth was said to be the acquisition of skilled people. The availability and retention of skilled staff were key issues for all the firms interviewed and a particular reason for doing business in London. Competition for top graduates within and across the service sectors is regarded as fierce, with much higher costs of recruiting and retaining good staff in London than in Frankfurt. The practice of importing specialist teams from competitors was said to be increasing. For example, the shortage of skilled lawyers was said to be leading to 'whole teams being poached' by competitors in the German market.

Human resource costs were seen as likely to rise in all service sectors in a competitive market of under-supply and increasing demand. In addition, some respondents were wary that intellectual capital is vested in individual staff members who are not a fixed asset. Some predicted the increasing development of strategic partnerships, joint ventures and cross-shareholdings to facilitate cross-market and cross-industry business developments. 
New partnerships creating whole new services within the new economy were discussed. One consultancy firm interviewed was said to be developing business networks that 'do not naturally fit an existing service market segmentation'. Some alliances could be formed with the smaller innovative start-ups that are entering emerging markets and with technology firms, commoditising services and moving away from intellectual capitalbased business models. E-business was seen as allowing innovation in the creation of new products and services for new cross-border markets.

\subsubsection{Operational tension: centralisation versus decentralisation}

\section{The need for operational centralisation}

Associated with an increasing demand for global provision of service, the demand for consistent 'seamless' service was discussed by many respondents. This was found to result in the perceived need to centralise certain functions and services operationally, but not necessarily geographically, to allow strategic decision-making and control and the development of global solutions. For example, one UK bank's product management for European centres, including Frankfurt, is centralised under a single project management structure in the UK, with operational processing outside London and 'treasury' in London. For a German bank headquartered in Frankfurt but with key global functions based in London, there is an increasing operational need to consolidate trading and settlement to control and manage risk.

For matrix organisations, industry and service or functional lines were found to be increasingly important dimensions for operational centralisation alongside the traditional geographic dimension. A large international law firm with a non-hierarchical partnership system of practice has a matrix management structure based on a product as well as a regional basis. While centralisation of operational governance was in one sense therefore seen to be increasingly non-geographic, with implications for firms' hierarchical relations within the wider space of flows, it remains the case that global network leaders tend to be based in global cities and, for most firms interviewed, at present this is more likely to be in London than in Frankfurt.

\section{The need for operational decentralisation}

Alongside the need for operational centralisation there was an equally strong perceived need for operational decentralisation to meet the demand for local interpretation of global products and solutions and customer relationship management. European customers have increasing access to information and power to choose between service providers, accentuating the importance for firms of being close to and 'knowing' the customer. For all services, homogeneity of common platforms, methodologies and crossborder charging was seen as requiring reconciliation with local diversity and difference.

Services were emphasised in all sectors as an increasingly 'people' and 'relationships' business 'with regional and global overlays'. Business was seen as requiring decentralised 'local' national decision-making and the ability to demonstrate a top position in local service industry rankings everywhere, including Frankfurt. In all cases, Frankfurt operations would be expected to be headed by German nationals who 'know' the local market.

While at present it was generally less common for Frankfurt-based staff to occupy global leadership positions, a number of respondents based in London European headquarters 
saw the position shifting. This could have significant implications for future hierarchical relations between operations in London and Frankfurt. For example, for one UK bank there is no contradiction in the drivers for operational centralisation and decentralisation:

It's a matter of investing in the things that still need to be local and rationalising the things that don't ... What the rationalisation opportunity gives you is actually the opportunity to invest in the local environment (Frankfurt) without all the pipes and plumbing that might stop you investing in other circumstances, so it makes you much more flexible, [allowing investment] on the ground.

Operational decentralisation can therefore be seen as potentially adding to Frankfurt's influence in cross-border service networks but also as increasing business relations between London and Frankfurt.

\subsubsection{Locational tension: concentration versus dispersion}

\section{The need for locational dispersion}

The high costs of locating in London were said by some respondents in both cities to have led to a long period of dispersion facilitated by IT, mainly involving staff in middle- and back-office functions who had no client contact. E-commerce was identified as increasingly important for cross-border business. A non-European foreign banker in London commented:

We'll move all our operations out, everything, over five years. Move to a cheaper environment, accountants, everything. But we want to keep the intellectual capital close at the moment until we can develop the technology that allows us to share intellectual learning and capital with each other ... That time's probably not very far away ... I sure wouldn't be thinking about putting them into Frankfurt either. I'd put these into Mumbai, Darwin, Australia ... Asia or whatever ... We operate custody operations in four different countries, we don't need to be in them. We want to be in a different place, cheaper, more efficient.

While dispersion is not a new business driver, some respondents saw the virtualisation trend in the economy and society associated with developing technologies as potentially leading to a changing spatiality of business relations. Potentially the logic of cost saving through outsourcing and geographical diversification, combined with organisational disaggregation and functional diversification in some business areas, could have major implications for the future of both London and Frankfurt as centres of service employment.

\section{The need for locational concentration}

However, another key trend was widely seen as the concentration of resources in fewer centres. For example, while the emphasis on the retail side of financial services is to 'put people on the ground', on the wholesale production side locational proximity remains critical. The need for proximity, depth of skills, financial infrastructure, knowledge and access to international corporate clients was regarded as a continuing key stimulus to clustering and concentration in the two cities, particularly London. As a non-European headquartered banker in London put it:

Face-to-face is still very important ... it's part of the team-building exercise. Centralisation also brings control and it's reinforcing the concept of identity and team 
... Obviously cost is an issue, it's much cheaper through economies of scale to have everyone in the same office ... Those are the critical issues - cost, control and promoting this team identity.

Proximity was seen as remaining essential for key staff in services business in London and Frankfurt in all sectors. Skilled staff were perceived as still preferring to work in city-based teams, and this was seen as important to skills and knowledge acquisition by employers. Some London-based respondents located outside the City itself spoke of the major disadvantages in terms of attracting staff and travelling to client meetings. In London and Frankfurt, central locations were regarded as remaining at a premium and as essential for building business and institutional relationships and intellectual capital.

\subsection{Resolutions and outcomes in cities}

Attempts to resolve the many tensions that face service firms in their provision of crossborder and global financial and business services take many forms, as we have just shown. In a dynamic globalising world these tensions are never 'solved'; rather they are managed in ways to accommodate, as competitively as possible, to contemporary conditions. Managing tensions may involve either intra-firm actions or inter-firm relations and, as we have seen, in both cases cities are directly implicated as business service centres. It is through this myriad of processes that service firms create the interlocks that produce the world city network. In our model, firms compete in the world financial and business services market and the outcome is a world city network. If this is the case then we would expect that evidence on inter-city relations should be marked more by co-operation than by competition. We focus upon the relation between London and Frankfurt, and each city's relations with selected other cities. In a further complication to the jigsaw, we find that the balance in evidence for co-operation or competition varies by scale of operation.

\subsubsection{Competition between cities: global and domestic scales}

Evidence for a London-Frankfurt conflict is all but missing from this study. This is the underlying reason why the launch of the euro and the Frankfurt location of the ECB are deemed to be unimportant in the relations between the two cities. Quite simply, the 'huge gap' or 'big difference' between the two cities means that London and Frankfurt are not really rivals. There may have been some small relative improvements in Frankfurt's position, especially in finance, but this has no immediate impact on London's role as 'the European metropolis'.

Where inter-city competition is mentioned, it is of a different nature. According to one institutional interview in London, 'London is not competing against Frankfurt, it's competing against New York'. London is seen as being at the very top of the world city hierarchy where it competes only with other such 'global cities' and not with Frankfurt, which is 'a sort of regional German city'.

The problem for Frankfurt is that 'there's a lot of competition between German cities'. As one London institution put it: 'if I would be Frankfurt I would be more worried about Berlin than I would be about London'. In fact the existence of a 'German system of cities' of which Frankfurt is just one member is a point frequently made. Whereas 'Great Britain 
is London', our respondents saw Frankfurt in relation to other German cities - Berlin is mentioned 21 times, Munich and Düsseldorf 16 times, Hamburg 15 times, Cologne and Stuttgart three times each, and Leipzig twice. Germany's more decentralised urban system (see, for example, Blotevogel 2000) means that although Frankfurt may lead in financial services, it is not the leading city for other services - for instance, Frankfurt is ranked by respondents behind Hamburg and Düsseldorf in advertising, behind Düsseldorf and Munich for management consultancy, and Berlin is identified as a future rival in legal services.

Clearly London and Frankfurt are seen to be engaged at two very different levels of competition. Despite the remit of this study, respondents talk very little about regional competition at the European scale. The idea of a 'triumvirate' of London, Paris and Frankfurt is mooted at one point, but competition between them is hardly discussed at all. In Europe it is complementarity and not competition that is emphasised.

\subsubsection{Co-operation between cities: European and global scales}

'There is no rivalry between offices' is the common refrain of our respondents, and therefore it is 'wrong to see it in terms of office versus office'. All firms operate through their network of offices to provide clients with the best international product they can. It is clear that market pressures on firms are creating co-operation across cities: 'We cooperate very strongly in Europe, that's something our clients demand'. The only example where there was competition between offices in the same organisation was where offices operated as autonomous profit centres; the norm, however, was to use network teams to eliminate intra-firm rivalry and 'pull together ... that's much more important than geographical issues'.

Contacts and flows between offices vary by sector and firm, depending on the mix of projects at any one time. But the interaction between cities is continuous: 'we are integrated, we talk every day with almost all our offices'. It is usual in one firm to have a Frankfurt person in London and vice versa every day. For another, 'co-operation between our London and Frankfurt offices ... has grown considerably in the last five years'. And the reason for this is the mutual benefits of being in both cities, as witness the use of London as a platform for global business by German firms and Frankfurt as a centre for German M\&A business by London-based firms.

And, of course, this is not just a feature of London-Frankfurt relations and Europe. Many firms mentioned other equivalent inter-city relations (Paris-London, New York-Frankfurt, Beijing-Frankfurt, for example). The response to globalisation has been to develop 'global management' because 'we are serving global clients and therefore we have to put together multidisciplinary teams from across the world'. The key operating units in all this are the office networks, and this synergy within firms has produced synergy between cities as the world city network.

The situation is best summed up by two London-based institutions. According to one, 'London is the European interface' and therefore the 'increasing strength of Frankfurt is feeding into London not draining away from it'. For the other, London is the 'bridgehead in Europe' for non-European inward investors and 'the two cities who benefit from this mainly are, at the moment, Frankfurt and Paris'. Mutuality, complementarity and co-operation are the hallmarks of a network. They are clearly present in the world city interlocking network within which London-Frankfurt relations are a prime example. 


\section{$4 \quad$ London-Frankfurt relations in a network society}

\subsection{The spaces of networks}

Castells (1996) has argued that the rise of a network society has resulted in spaces of flows coming to dominate spaces of places. In globalisation this is represented by the challenge to the mosaic space of nation-states by 'borderless', communication/computer-based processes, for example in international financial markets. Castells recognises the world city network as a prime result of the creation of such new global spaces of flows. Within this interlocking network there are many flows beyond the office linkages discussed in the previous chapter. Four important networks that constitute London-Frankfurt relations are the following: knowledge networks, cultural networks, power networks and governance networks.

In this chapter we consider how our respondents report these different networks of flows to inform London-Frankfurt relations. Sections 4.2-4.5 consider each of the networks in turn. Section 4.6 examines the space of inter-city flows in interweaving networks. The key findings are as follows:

- Knowledge networks have the potential to revolutionise spaces of flows and redefine shifting relations between London and Frankfurt.

- Cultural networks are a key determinant of, and stimulus to, inter-city business relations.

- $\quad$ Power networks exhibit shifting relationships and strong mutual dependencies that reflect established patterns of investment.

- Governance networks reach out between the cities regulating and shaping London-Frankfurt business flows through a web of public-private and local-global relationships.

- Interweaving networks are characterised by proximity, connections and complex interdependencies making co-operation integral to inter-city relations.

\subsection{Knowledge networks}

\subsubsection{Knowledge flows}

Service business was widely perceived across the sectors to involve flows 'of the knowledge in people's heads' and the generation of ideas through organisational networks. The interview responses indicated that inter-city co-operation is essential for firms to take full advantage of technological developments in the transfer of knowledge within networks. 
Discussion of business flows between London and Frankfurt revealed that 'local' inter-city flows are highly interconnected with wider networked flows of knowledge and finance. One globally structured consulting firm with offices in both cities told us:

The way in which we're structured, actually which office people are based in, matters not at all to us ... we draw people from wherever they may be ... or we create a virtual network, so wherever people are based they'd be contributing to the project ... where people sit doesn't matter ... I wouldn't actually know where they're sitting. I pick up the phone, I just ring the number.

Knowledge was discussed as being made available virtually, anywhere through a network. For example, one banking respondent in London said: 'You can do it from almost anywhere, and it's only some of the old regulatory structures and things like that that are almost keeping the physical'. An advertising respondent in Frankfurt put it thus: 'It is out of the network that ideas are being generated ... it doesn't really matter whether this person is in Hamburg or Frankfurt because they take their network with them.'

Knowledge is increasingly being transferred from London to Frankfurt. To take some examples just from accountancy:

We're sending people from here [London] to develop properly skills of people on the ground so they can service the client there [Frankfurt].

We are migrating skills to other European countries, particularly Frankfurt.

You have to be clever and bring the resources to wherever they're needed.

The liquidity of intellectual capital and finance was seen as opening up possibilities for new spatial relationships between the individuals that comprise networks globally and between firms and markets. ICT and e-commerce were widely discussed in all sectors not just as mechanisms for transmitting information through networks but as a future key medium for engaging with markets. Deregulation and IT were seen as allowing the instantaneous flow of finance across borders. Business flows generated in any one city were seen as increasingly reaching out to distant markets through e-commerce, changing the geography of business relationships. These developments will redefine the space of business flows between London and Frankfurt.

\subsubsection{Knowledge and relationships in 'people' business}

The development of a virtual, client-relationships business model was seen as a key future means to expand business reach and scope and engage with cross-border markets. This was widely discussed in financial services where in the retail sector there has been a shift away from a high-cost local place-based, branch-centric model. For one London-based banker this could explain

why some of these apparently attractive cross-border opportunities [with Germany/Frankfurt] are not happening ... I can do it with a lot of cost and a lot of pain and I'm not quite sure how much value that will account for. Or I can do it that way, through the internet and build the brand. Generally that way looks more attractive. 
Other non-German banks based in London saw a European e-commerce strategy as making financial sense for retail business: 'We've not had much success with a bricks and mortar strategy in terms of developing business in Europe, so I think it's more likely we would have more of an e-commerce type strategy.'

While European services headquarters remain concentrated in London, business flows to German and European markets that originate or pass through London could potentially, through e-commerce, increasingly either be directed through or bypass Frankfurt. Even German-headquartered banks may or may not channel retail business through Frankfurt, as revealed by discussions with respondents in London. Technology is seen as offering economies of scale for the 'big swath of customers' but also as facilitating customer relationship management for the expanding wealth management business associated with European demographic change.

\begin{abstract}
When we look at the internet ... I think it's going to lead to a bifurcation. Down here we can have an execution platform and a research platform that interfaces with customers with little human touch ... but here we're going to use technology for something else, so I can speak to the best customers so they can get the most intimate service ... like they're an intimate part of the firm.
\end{abstract}

However, local market knowledge and client relationships were also widely recognised to be increasingly essential in a competitive 'people' business. The need for local physical presence within Germany was also prioritised in all sectors as a necessity in building client relationships and in moving from a product-led to a service-led business model. A German respondent in advertising commented that 'one of the advantages of a network [is that] if you have to do something in another country you can adapt it [but that] you'll have to have the people there who can smell and feel and know that and who can then realise it'.

But 'local' German operations will not always be centred in Frankfurt, even in financial services. The flux between competing knowledge supply and demand drivers is likely to lead to shifting global-local business relationships. For example, German banks with offices in London spoke of an increasing need 'to be close to the customer where the centres of demand are' in Germany and Europe. For some British banks, 'there has to be a real business reason ... there would have to be a real demand to operate a specific operation out of Frankfurt'. For another, being represented close to the market is a necessity: 'We kept our service functions [in Frankfurt] on the ground and invested in them'. One Asian bank is expanding in Frankfurt because of its focus on German corporate customers and maintaining a small representative office in London. A continental European bank commented: 'We have a presence in Frankfurt to reflect the current role of Frankfurt in the equity markets ... our options are open with regard to Frankfurt at the moment but the concentration of investment presently is elsewhere [London]'. 


\subsection{Cultural networks}

\subsubsection{City people and business cities}

Interviews also emphasised the fundamental importance of the fact that the people that constitute firms in both cities are individuals who are locationally situated and personally and socially, as well as corporately, motivated. For many respondents the location of workforce has become more important than location of customers.

City-based cultural networks are a key factor in determining future relations between London and Frankfurt. This was particularly evident in advertising: 'We need to be able to recruit good people. As far as our location in London's concerned we can get good people, "creatives" and "suits".' This is not true for Frankfurt-based agencies: 'It's extremely difficult to attract German top advertising people to Frankfurt ... there is no inspiring environment here'. One problem for Frankfurt was that the 'English, Americans or French are not very keen to come to Germany, that's almost non-existent'. According to a non-British consulting firm with a European HQ in London:

From the client service point of view, personally, I don't think it's important that we have an office in London at all ... but from a point of view of building esprit de coeur, building capabilities within the team of consultants ... we should be based out of Heathrow, that would make economic sense, but there might be a revolt ... certainly the younger consultants ... for emotional reasons, social reasons, they might not be so keen.

The difficulty of recruiting people in Frankfurt was emphasised by respondents in both cities, and attitudes of non-Germans and Germans based in London to Frankfurt as a place to live were generally negative across all services. Comments most often focused on Frankfurt as 'boring' or 'dead from seven or eight o'clock at night'. This negative perspective on the part of an international workforce was recognised by respondents in Frankfurt. As one legal firm put it, 'The quality of people I have recruited has become better, but it is arduous. If we can't find people in Germany, we try it internationally but it involves higher costs to get people to move to Frankfurt and there is the language problem'.

Frankfurt-based German respondents had more positive personal attitudes to the experience of living in Frankfurt. To take an example again from a legal firm: 'I believe that Frankfurt is attractive. It's not a big city like London or Berlin but it offers a lot of things these cities offer like culture, theatre, opera. Not on the same scale but with an attractive programme. We have the advantage of the airport ...'.

\subsubsection{City cultures and city business}

City cultures - amenities, architectural heritage and cultural life - will be critical to the cities' business relationships. An American respondent based in London speculated that:

With modern technology ... it doesn't matter whether [markets] are in Frankfurt or in London or even Timbuctoo ... people have to live somewhere but you could imagine the relative importance of financial centres being dictated by quite different things from where's the most liquid market, because the liquidity can flow from anywhere - 
where's the most pleasant to live, theatres, restaurants and all sorts of secondary issues.

The most globally oriented firms' London offices now typically have international staffs, and the reflection of cultural difference within city-based networks is seen as essential to engagement with local markets. One investment bank has skilled employees from all over Europe and all over the world at senior levels in London to reflect diversity in an increasingly 'less defined' world.

There are signs that Frankfurt's increasing connections through business relations with London are intensifying cultural flows into the city. Long-standing London-US service sector business relations were widely regarded in London and Frankfurt as promoting dominant Anglo-Saxon cultural and business flows into Germany and Frankfurt through global network brands. Recent mergers and acquisitions in legal services illustrate the point. For one law firm, the issue is how to get new German partners 'brought into this brand'.

Cultural flows between London and Frankfurt were seen as essential to cross-border business relations. Typical of Frankfurt-based lawyers' comments was that 'Frankfurt is probably the German city that has opened up most to Anglo-American culture'. London firms were very aware of substantial national cultural differences in the way law is practised, and emphasised the challenges in achieving cross-border synergy. A Frankfurt respondent commented:

\footnotetext{
Well the real problem are the English ... the English have never worked internationally and they have never lived internationally ... If international work or life means to speak another language and immerse in another culture, then you won't find that with the English.
}

The representation of cultural difference in inter-city relations was seen ambiguously in London and Frankfurt but what was agreed was the importance of cultural flows and cooperation as a stimulus to inter-city business. A key debate centres on the issue of full organisational integration versus formal co-operation between separately controlled entities. The research sample included firms in Frankfurt and London in both categories. It would seem there is no general agreement at present on what works best. One Frankfurt-based view was:

I'm not a friend of these mergers. I think we should find ways to actually get a kind of equality in the co-operation between London and German law firms and avoid the dominance of either side ... sometimes you have to say no to a deal and this freedom is part of our ethics.

Yet two Frankfurt-based lawyers interviewed believed that alliances are not as good as real mergers because you can't offer 'a seamless service'. Another expressed a positive view that 'London has acted as a model for Frankfurt and Frankfurt has profited from looking to London'. The emphasis in both cities on finding solutions to cultural differences illustrates the importance that is attached by firms to inter-city co-operation. Cultural flows associated with co-operative business relations were widely seen as beneficial to business in London and Frankfurt. 


\title{
4.4 Power networks
}

\subsubsection{Flows of influence}

Interviews indicated that for most top services firms, global leadership positions tend to be located in at most eight to ten global cities. Within Europe, at present, overall more key senior staff are located in London than in Frankfurt, with implications for decisionmaking and global influence.

Among the advantages of London over Frankfurt for key staff, English as the international business language and the multilingual environment were emphasised, as well as the cosmopolitan social life and culture. The fact that London is favoured by Americans, and particularly the American investment banks, was seen as absolutely critical to London's success as a financial services centre and to business development for other service firms. London's capacity to attract international inward flows of investment, particularly from the USA as the world's dominant economy, as well as its cultures and critical mass of skills and knowledge were perceived as generative, attracting more flows into London and determining international flows to Frankfurt.

London's dominance within the UK was seen as a major advantage in attracting inward flows of power that give London influence over Frankfurt. A Frankfurt-based respondent expressed a common view of the relationship between London and Frankfurt from the German side:

\begin{abstract}
this [take-over of German law firms] doesn't strengthen the location here. It weakens Frankfurt because Anglo-Saxon law firms are organised in a way that the interesting work is done in London ... here they will only ask for local opinions about local characteristics of the German market. That means that big business is taken away from Frankfurt and is being done elsewhere ... Our law firm is structured very differently ... we have opened an office in London but not to be part of a London-based organisation ... we realise that we can get interesting business in London, some of it related to Germany, which we wouldn't be able to get in Germany. And that's very interesting, where these business flows are, the decision centre for many things is London and not Frankfurt.
\end{abstract}

Nevertheless, London was widely regarded by people interviewed in both cities as having a pivotal global capital market location that is helpful to business in Frankfurt. The concentration and proximity of financial service markets, skills and experience in a single location results in economies of scale and scope that were seen to benefit Frankfurt. At the same time London was seen as benefiting from Frankfurt's European business networks suggesting a powerful mutual dependence. These findings suggest that, as proposed in Section 3.4.2, in interlocking city networks, relations between London and Frankfurt reflect a complementarity of interests.

\subsubsection{Shifting relationships}

Frankfurt was described by respondents in both cities as remaining essentially a service centre for the local German/European market. Remaining disjunctions affecting Frankfurt's wider international connections were seen as skills (knowledge networks), cultural difference (cultural networks) and regulation (governance networks). However, Frankfurt-based firms' proactive response to European regionalisation was widely seen as 
spurring not only the development of cross-regional networks within continental Europe but also a shift in Frankfurt's connections to wider international flows.

To compete internationally, German firms were seen as requiring London-based representation. For example, German banks were seen as having no choice but to operate out of two centres, London for international markets and Germany for the domestic German and European market. Increasing German and other foreign ownership of firms in London was seen by some respondents based in both London and Frankfurt as creating strong London-Frankfurt interdependencies and a power shift between the cities that could make London vulnerable to future cross-border movement of resources. The issue of risk associated with the openness of cities to foreign ownership was raised by some respondents in both cities, but 'Wimbledonisation' was most typically seen by London respondents as providing infrastructure for business that otherwise would not be present and therefore not detracting from London's success. Co-operation between the cities was prioritised over competition.

Increasing German interest in international relationships was associated with a shift of influence within service networks. A London-based respondent reflected on recent changes within one accountancy firm's international network:

We've had to, over the last seven or eight years, really encourage our German colleagues to take senior international positions ... Now it's unrecognisable ... Not only because we've encouraged them ... they realise that this is fun and there's a chance to become more international.

Combined with further restructuring of regulative processes, the professions and training, this change of attitudes from a national to an international perspective was seen as increasingly opening Frankfurt to inward global flows.

Changing power relations between London, Frankfurt and New York within global networks were indicated by some respondents, and some expressed concerns that London-based business could suffer in the long term from political isolation and disfranchisement within Europe. An analogy was drawn by one respondent between informal EU euro-group meetings that exclude the UK in deciding important European matters and changing decision-making practices within global service networks. However, power relations were also seen as constructed by the scale of existing infrastructure and resource investment. A newly elected European leader in one international firm will almost certainly move to London: 'This, rightly or wrongly is where the European leadership sits ... if he wanted to change the European location of course he could do that but it's a bit of an effort because there's a little bit of infrastructure!'

Frankfurt's position as one of a number of decentralised cities competing for business in Germany was seen as a disadvantage to the city's growth and power relative to London. In a federal system, shifting relations also mean increased competition for Frankfurt firms within Germany. For example, proposed changes to the German system of state and commercial banking will spur domestic competition, but while German banks are aware of the need to protect their home market and keep close to the customer base in Europe, business flows will not necessarily require a substantial physical presence in Frankfurt. A German respondent based in London explained: 
Berlin is emerging very much indeed ... It only needs one bank to say we need to have our strategic headquarters in Berlin ... You have got this beautiful edifice in Frankfurt glittering away during the day and at night just staffed by staffers and Frankfurt will think, oh well really the decisions are being made in Berlin rather than Frankfurt. It doesn't take much.

However, there is no evidence of such a development yet. It is Frankfurt that has gained most from competition with other German financial centres (Schamp 1999).

\subsection{Governance networks}

\subsubsection{Regulation of cross-border flows}

Regulation through state and inter-state intervention was seen as a key determinant of cross-border business flows. Regulation was cited as an important factor in determining firms' locational decisions, and balanced regulation was widely regarded as necessary to support the smooth running of cross-border markets and provide investor confidence.

Continuing regulatory change and progress towards a single European market was regarded as important to remove obstacles to cross-border business. The integration of financial markets and the outcome of the Lamfalussy (Committee of Wise Men) proposals were seen as potentially having key effects on future London-Frankfurt business relations for all the service industries. The development of a single efficient European securities market to maximise liquidity, speed and transparency was seen as a key determinant of future London-Frankfurt business flows. However, some concerns were expressed in both cities about loss of national powers. National (UK and German) power was seen as being weakened by the introduction of Europe-wide regulation and legislation.

The changes were seen as being far greater for Germany as it is required to open up bringing the German business world more closely into line with international practices. The UK Financial Services Authority was generally perceived as having considerable influence, and the German government has recently announced plans to create a single independent regulatory body for financial market supervision that would combine the tasks of the previously separate agencies for banking, securities and insurance, and reform the Bundesbank at the same time.

The need for harmonisation of national standards of professional and business practices was widely stressed across the service industries. Differences in national regulations and cultural differences in the way services are provided, not only within Europe but globally, were emphasised as having a major influence on cross-border business flows. For example, the harmonisation of accounting standards was seen as having future key effects on European markets and services. One accountancy respondent referred to auditing and advisory business as currently 'driven by the US Stock Exchange without much of a counterbalance from any other European regulatory authorities. The US stock exchange rules the world.'

The issue of whether common EU standards, including professional training, will add to or detract from business flows between London or Frankfurt was discussed. The 
important issue was seen to be achieving a level playing field and, for London respondents, ensuring that the UK has equal access to the single market if it remains outside EMU. A major concern for London respondents was also that EU directives should be consistently implemented in each member state. It was generally thought that there will be more reason to do business in Frankfurt, but that this will not necessarily damage London - both cities are likely to benefit. Frankfurt is catching up as a services centre in a range of ways so that London was generally seen as eventually losing some of its existing advantages, but the development of business in Frankfurt was also seen as adding to business in London as long as London remains open to international flows of skills and investment. This finding again lends support to the theme of inter-city cooperation, this time in relation to both public and private sector institutional regulators.

\subsubsection{Geographies of public-private governance}

Changing business relations between the cities were found to be determined by a complex interweaving of public and private sector relationships. Interviews with firms and institutions in both cities suggested that formal public governance is subject to a whole range of different and sometimes conflicting priorities reflecting administrative boundaries and public-private relationships. While formal state institutions are nationally based, networks of public-private governance reach out through a wider space of flows challenging traditional boundaries.

Cross-cutting relationships between firms and senior public and private institutions were found to be common in both cities, but public-private networks were generally seen as more orchestrated and co-ordinated in Frankfurt than in London, where relationships were perceived as more informal. Public institutions, trade associations and professional bodies carry out active lobbying and promotion of business interests in both cities. However, perspectives on the roles performed by public and private city institutions suggested significant differences. Direct inter-city institutional relationships between the cities were represented as frequently close at a personal level but currently undeveloped formally. Some London-based institutional respondents suggested that stronger inter-city institutional co-operation would be beneficial to business in both London and Frankfurt, citing other examples of successful inter-city institutional relationships.

Within London there was a strong emphasis on maintaining an open and level playing field for international competition, while within Frankfurt a greater focus on internal growth was perceived. Some London commentators suggested that a more formal London-based intra-city decision-making strategy between key public and private organisations based would be helpful to City business. However, the predominant view was that it is the agency of a multiplicity of individual foreign and British market interests within London that leads to the City's success as a node for international business. Public-private relationships centred within the City represent international as well as UK interests, reflecting the scale of foreign ownership and giving London a key role in governing the web of local-global business flows.

However, institutional structures were found to cause conflicts of interest, with key effects on flows of business. Within the UK, the Treasury was cited by a number of institutional respondents as having a serious conflict of interest in its role as sponsor of the financial services industry and regulator/taxer of the economy as a whole in relation to stamp duty. In Germany, conflicting interests are associated with the decentralised structure of public and private governance and the separation of Frankfurt as a financial 
centre from the political capital. Many trade organisations and professional bodies are not principally based in Frankfurt but in Berlin or elsewhere, and cannot (and often do not intend to) promote one city as forcefully as in London. For example, Finanzplatz e.V., the association representing the interests of the German financial community, although based in Frankfurt, explicitly promotes Germany as a financial location and not Frankfurt as a financial centre. The Bundesverband deutscher Banken, representing the interests of German non-public banks, is located in Berlin to be close to the centre of political decision-making. Similarly the Deutsche Bundesbank has not been able actively to promote Frankfurt as a financial centre due to its decentralised decision-making structure. These examples of conflicting institutional interests were clearly believed to be damaging to cross-border business flows.

\subsection{The space of inter-city flows in interweaving networks}

In Chapter 3, the complexity of London-Frankfurt relations was conceived as a set of interconnecting tensions represented by market forces, client demand for services and industry response. Studying inter-city relations as flows within networks reveals strong interdependencies between the social processes that constitute cities and service industry relations. Interweaving networks of firms, knowledge, culture, power and governance shape the geography of service fields and the formation of clusters in city locations. Here we examine the space of London-Frankfurt inter-city flows associated with the interlocks between these networks.

\subsubsection{Geography matters less - proximity matters more}

Many respondents took the view that in one sense networks mean that geography matters less: 'where people sit doesn't matter', they take their networks with them. With world-wide mobility of capital and instantaneous communication, for some, 'geography is irrelevant'. A London-based German banking respondent commented in relation to Frankfurt:

There's a financial infrastructure but there's also a corporate world out there that we're ultimately here to service and ... a world out there of people managing other people's money which is clearly not so motivated by location at all.

For firms represented in both London and Frankfurt, this point was emphasised by responses to questions about staffing levels and flows of staff between the cities. One German bank specifically operates a 'virtual office' between London and Frankfurt. A general manager said: 'You ask me questions about how big is our office in Frankfurt and London. I've no idea. I don't know.' Generally, respondents could not see the relevance of studying relations between the two cities: 'Frankfurt and London - what does it mean? ... Does it really matter? and I think increasingly we get to the point where we say it doesn't matter'.

Yet all respondents also emphasised the increasing importance of physical proximity within networks. In a globalised 'people' business, the significance of social proximity, face-to-face contact and trust-building relationships, knowledge and intellectual capital, was emphasised across all services. Firms' intellectual capital was seen as concentrated in 
major cities, where key people are locally situated and globally networked. While intellectual capital is networked, knowledge is still communicated face-to-face and through informal means, by chance meetings in City streets, in bars and on transport. Respondents in both cities emphasised the importance of proximity for knowledge transfer between firms, within and across industries.

Frankfurt-based responses included the following:

Despite all these wonderful telephone and video conferences and e-mail ... you always need personal contacts, personal talks, you've got to see the man, you've got to know how he reacts ... the creation of new products can't be done in a thousand places around the world .... intelligent people who create something new are concentrated in a few special places ... because it's easy to communicate.

In Europe you have to be in Frankfurt and London because that's where the main business is and because all say it's in London and Frankfurt, all move to London and/or Frankfurt, that's a kind of self-fulfilling prophecy.

In London these comments were typical:

You learn your skills from other people, so you can't learn your trade by just being stuck somewhere in Bangalore and ... give it a proper value-added unless you have some contact with the rest.

At this point in time and historically, proximity has been a big issue and for that we mean physical, mental, cultural as it were ... Now maybe it's getting broken up because of technology, the stock markets in London and Frankfurt beginning to merge, some of those things will change but they're much more transactional. Where relationships matter, facilitation matters, interpretation matters, I think we need proximity.

\subsubsection{The importance of connectivity in inter-city networks}

As indicated in Section 3.3.2, the important feature of business networks is their connectivity across space. In both cities increasing use of virtual communication was seen by many respondents to add to the need for inter-city face-to-face communication through physical presence in and travel between London and Frankfurt.

There is increasing German services representation in London, and travel between the cities is increasing. A German respondent based in London noted:

The fundamental difference I see when I travel between London and Frankfurt twenty or thirty times a year [is] an increasing amount of bankers. It's amazing how this traffic increases. In that sense those two cities are moving closer together.

However, a major difference between the cities was seen as the degree to which they are connected to wider flows. London's importance as a location for international business was consistently associated with its geographically situated concentration of virtual global and local connections.

Two bankers based in London whose operations were headquartered outside Europe commented: 
Trading could centralise in one global location, London ... It's a great markets location, it's a very capital markets location ... you need to know what's going on in Japan and the West as it affects whatever you're doing here and that's the key, you get it all right here. I could see having centralised trading in one location in the world in ten years or five years ... why don't we just have a 24 hour shop here? ... halfway between big financial centres just physically - geography's helpful there.

It's a very difficult issue but it's this idea of critical mass, almost fashion, the concept of, you have to be there, it's the happening place ... it's terribly, terribly important ... we're trying to pack more and more people together on to the dealing floor so we're all together ... you downsize the satellites and you pump up the centre ... your clients are doing the same thing. No wonder London's thriving.

Frankfurt-based law respondents' comments included the following:

London is the place to be in England because of its central functions. In Germany that is more differentiated.

Great Britain is London....

In Germany that's different ... in a federal system like Germany you don't have to be in the capital to be successful.

It's still ... essential in London that it's a people business and you generate things through empathy and how you get on with individuals.

London's openness to foreign investment and inward flows has encouraged business to settle, contributing to the City's scale and critical mass of intellectual capital, cultures and influence as an international services centre. The volume and strength of these flows is generally perceived as making them hard to dislodge. As one London institutional respondent commented: 'You can never be sure ... there are some circumstances in which a single-minded strategy can backfire but it doesn't seem so at the moment'.

London's global connectivity was consistently represented as beneficial to business in Frankfurt. A Frankfurt banking respondent made the point. 'If you ask me "Is Frankfurt part of London?" I would be happy to say yes ... if it was one place, then Frankfurt would have a chance'. As a globally connected city, London does not seem to challenge or be threatened by relations with Frankfurt - so far the growth of both cities has been boosted.

This conclusion is supported by a statement in a recent published interview with the president of the Bundesverband deutscher Banken, the federation of German private banks, who states: 'you shouldn't think in terms of zero-sum games. Concentration processes are beneficial to all parties involved, because the market is getting bigger and more efficient. All financial centres involved will profit from the resulting growth' ('Die Zukunft des Finanzplatzes Frankfurt liegt in den Händen der Finanzdiensleister', FAZ, 8 November 2000).

\subsubsection{Connections are replacing boundaries in the space of flows}

Our research findings support the thesis that in a networked society, flows take precedence over borders. Place- and role-related boundaries are becoming more blurred and less relevant, suggesting that the processes driving future relations between London 
and Frankfurt will be less defined. Increasingly, national borders are seen as less significant to business flows than inter-city connections. The lines between people as market consumers, workers within and owners of firms, are becoming more obscure. Key staff within the service firms interviewed are individuals whose actions will be influenced by increasingly interconnected personal, social and financial as well as corporate goals.

The growth of local (UK and German) and global share ownership was discussed by a number of respondents as a key future driver of changing inter-city relations in three related ways. First, within Germany, a tradition of private ownership of companies has meant that business advice has not been demanded until relatively recently. Now with mergers and acquisitions, and change in the shareholder environment related to the European pensions revolution, firms within Germany have to be accountable, leading to an increasing demand for producer services in Germany, including Frankfurt.

Second, these changes were believed to be highly significant in determining future business restructuring within Germany. The adoption of a 'shareholder value' approach by corporate management was seen as a positive driver for business in Europe, leading to increasing cross-border business flows which will again be reflected in service business growth in Frankfurt.

Third, shareholder power was seen as directly driving the process of globalisation and corporate restructuring between the cities. In one American investment bank based in London and Frankfurt, employees own 10 per cent of the bank and are the single largest shareholder as an aggregate pool of investors, bigger than any mutual fund. One US investment banker commented:

\footnotetext{
What has caused this big push in the States, globalisation etc? ... now it's people who have investments and equities in mutual funds, pension funds etc. ... investors can get together and remove a management ... we're just starting to see that here ... people in Europe will become very demanding ... the shareholder argument is what's going to change Europe faster than the cultural changes ... in terms of globalisation, corporate restructuring in Europe, the push is going to come from the shareholders as well as the market place in general and countries will be bypassed if they resist ... The Vodafone management broke the back of Germany - they won't any longer resist that. And actually those kind of landmark deals will break the back of every other country. But if you protect your home turf from global capital, you'll be bypassed. Just like in World War II when they leave a strong point and go back to it later and they're surrounded. You go on, that's where capital will flow, to a receptive place, not a place that's massively resistant.
}

In a future mass European shareholder society, the cross-cutting socio-economic and public-private flows within interweaving city networks will be increasingly complex.

\subsubsection{Competition and co-operation revisited}

As place and role boundaries fade and complexity increases in a networked society, traditional distinctions between city competition and co-operation are likely to have less relevance to the reality of inter-city relations. The need for proximity and connectivity in service business and increasing interdependencies between economy, society and governance make co-operation integral to contemporary and future inter-city relations. 
Throughout our examination of inter-city networks in this chapter, co-operative relations have been shown to take precedence over competition as a stimulus to business flows that benefit both London and Frankfurt. Inter-city co-operation is clearly essential to firms and, as we argue in Section 4.5, inter-city co-operation within the institutional sphere could also be beneficial to both cities.

Finally, although not a core topic within our investigation, serious concerns about London's transport, congestion and environmental problems, skills shortages, housing costs and the sustainability of further economic development were expressed almost universally in the London interviews. In many cases, respondents indicated that these were the only reasons they could imagine for moving from a London location. Again, these are compelling reasons for inter-city institutional co-operation in addressing the policy, investment and governance challenges associated with successful global financial centres. 


\title{
Appendix 1 \\ Firms interviewed in London and Frankfurt
}

\section{London}

\author{
Banking \\ Abbey National \\ Barclays * \\ Bayerische Landesbank Girozentrale London \\ BNP Paribas London * \\ Chase Manhattan London * \\ Commerzbank London * \\ Deutsche Bank London \\ DG Bank London \\ Industrial Bank of Japan, London \\ Royal Bank of Scotland

\section{Law} \\ Cameron McKenna London \\ Clifford Chance * \\ Freshfields (Bruckhaus Deringer) London * \\ Slaughter \& May \\ Accountancy \\ BDO Stoy Hayward \\ KPMG \\ PricewaterhouseCoopers
}

\section{Advertising}

Diversified Agency Services, Omnicom

Ogilvy One Worldwide *

Publicis *

\section{Management consulting}

Andersen Consulting (Accenture)

A.T. Kearney *

Cap Gemini, Ernst \& Young

PricewaterhouseCoopers

Towers Perrin * 


\section{Frankfurt}

\section{Banking}

Barclays Bank Plc Frankfurt *

BNP Paribas *

Chase Manhattan *

China Construction Bank

Commerzbank *

Crédit Lyonnais SA

Dresdner Bank AG

J.P. Morgan

Société Générale SA

\section{Law}

Baker \& McKenzie

Clifford Chance Pünder *

CMS Hasche Sigle Eschenlohr Peltzer Schäfer

Freshfields Bruckhaus Deringer *

Morgan, Lewis \& Bockius

Oppenhoff \& Rädler, Linklaters \& Alliance

\section{Accountancy}

Arthur Andersen

Grant Thornton

Haarmann, Hemmelrath \& Partner (RSM International)

\section{Advertising}

Boebel/Adam (Publicis) *

McCann Erickson

Ogilvy \& Mather *

\section{Management consulting}

A.T. Kearney *

Towers Perrin *

* Firms interviewed in both London and Frankfurt. 


\title{
Appendix 2 \\ The grade of personnel interview in London and Frankfurt
}

\author{
Chairman (2) \\ Chief (includes economist, executive, operating officer) (7) \\ Partner (includes lead, senior, managing) (13) \\ Director (9) \\ Managing director (11) \\ Vice-president (includes vice-director) (5) \\ Manager (includes business, project, general, strategic) (8)
}

N.B. Specific occupational titles have been aggregated to protect confidentiality. 


\section{Appendix 3 \\ Firms' questionnaire}

\section{'Face-to-face' interview questionnaire}

\section{General context}

Frankfurt. According to a study by the American channel CNBC, carried out before the introduction of the euro, 39 per cent of the economic experts involved said that Frankfurt was likely to outdo London as a financial centre by the year 2005.

London. A London Chamber of Commerce survey of 100 foreign banks said (press release, 13 June 2000): 'Euro not an issue for the City - yet'. It was the 21 st of 23 factors influencing location, but 35\% said membership was necessary to secure London's longterm future as a financial centre.

1. From your experience working in Frankfurt does that make sense to you?

2. General changes since introduction of euro?

3. Do you think Frankfurt is catching up with London?

\section{Doing business}

4. Changes in functional business relations between Frankfurt and London? Why in London (Frankfurt), not in Frankfurt (London)? Division of labour/Core activities in each city/No. and specialisms of partners/Turnover/No. professional fee-earning staff/Cost centres/Location of chief executives/HQ relations/Level of integration.

5. Changes in organisational strategy/hierarchical relations between London and Frankfurt? How do you deal with business in London (Frankfurt) and at HQ? Consequences in terms of practical work? (Bigger or smaller/Partner in charge/Flows of personnel/Assignments per year/Arrangements for moving personnel between cities/Percentage of non-British or non-German employees/Relationship with HQ/ Relationship with other offices/'Pecking order'/Level of integration/ Communication between offices in both cities and HQ - business travel, fax, email, video conferencing

6. Changes in firm's locational context - relations with other cities/firms/ institutions/state locally and/or globally? Quality of local interactions/Wellembedded $v$ client-led (parachuting)/Global strategy/Networking/Market regulation - ECB, EU regulations/Culture and language

7. Are there any key issues we've not covered?

\section{Sector perception}

8. Typical for sector? How is sector responding to the euro with respect to Frankfurt-London relations?

9. How are relations between the sectors changing within/between cities?

10. Are there any key issues we've not covered? 


\section{Telephone questionnaire}

(Specific prompts included for each firm based on review of transcripts and newspaper articles.)

\section{Firm/sector}

Changes in business operations (internal and external) since first census period?

Implications of any changes for London-Frankfurt business relations (for firm/sector)?

Functional, hierarchical, local-global interactions.

\section{General context}

Likely effects, if any, of the recent UK government announcement on a decision on entry to EMU within 2 years of the forthcoming general election?

\section{Institutional context}

Changes in institutional context - market regulation (relation to ECB, EU regulations, state) since first census period? 


\title{
Appendix 4 Institutions interviewed in London and Frankfurt
}

\section{London}

\author{
Bank of England \\ British Bankers' Association \\ British Invisibles (International Financial Services, London) \\ Confederation of British Industry, London \\ Corporation of London (Economic Development Unit) \\ Financial Services Authority \\ London Chamber of Commerce \\ London First Centre \\ London Stock Exchange \\ Management Consultancies Association \\ The Law Society \\ The Institute of Chartered Accountants for England \& Wales \\ The Institute of Practitioners in Advertising \\ Chartered Institute of Bankers* \\ Department of Trade \& Industry* \\ Greater London Authority* \\ HM Treasury* \\ The Institute of Management Consultants*
}

\section{Frankfurt}

Deutsche Börse AG (Stock Exchange)

Deutsche Bundesbank

Finanzplatz e.V., Frankfurt

Gesamtverband Werbeagenturen GWA (Association of Advertising Agencies)

Landeszentralbank in Hessen

Verband der Auslandsbanken in Deutschland e.V. (Association of Foreign Banks in Germany)

Wirtschaftsförderung Frankfurt GmbH (Frankfurt Economic Development Corporation) Wirtschaftsinitiative Frankfurt Rhein-Main e.V. (business initiative promoting Rhine-Main area).*

*Telephone contact. 


\section{Appendix 5 \\ Institutions' questionnaire}

\section{Interim results}

- $\quad$ Effects of euro - Future of London as a financial centre relative to Frankfurt.

- $\quad$ Shaping of London-Frankfurt relations.

\section{Questions}

1. From your experience working in London does that make sense to you?

2. General changes London/ Frankfurt since the introduction of the euro?

3. Do you think London is catching up with Frankfurt?

4. What links/ networks exist between this institution and those -
(a) in Frankfurt/Germany?
(b) in London/UK?
(c) in Europe?

5. Are there any key issues we haven't covered? 


\section{Bibliography}

A.T. Kearney (2001) Investor Capitalism - A White Paper on Repositioning to Maximize Corporate Wealth. Chicago: A.T. Kearney.

Athaide, T. and Cornish, C. (2000) The Decision to Join the Euro and the Impact on Inward Investment in London. London: London First Centre/The Future Foundation.

Bank of England (2000a) London as an International Financial Centre, August. London: Bank of England.

Bank of England (2000b) Practical Issues Arising from the Euro, November. London: Bank of England.

Bank of England (2001) Practical Issues Arising from the Euro, June. London: Bank of England.

Beaverstock, J.V., Smith, R.G. and Taylor, P.J. (1999) 'A roster of world cities', Cities, 16, 445-458.

Bindemann, K. (1999) The Future of European Financial Centres. London: Routledge.

Blotevogel, H.H. (2000) 'Gibt es in Deutschland Metropolen? Die Entwicklung des deutschen Städtesystems und das Raumordnungskonzept der "Europäischen Metropolregionen"', in D. Matejovski, (ed.), Metropolen: Laboratorien der Moderne. Frankfurt am Main: Campus, pp. 179-208.

Bördlein, R. (1999) 'Finanzdienstleistungen in Frankfurt am Main. Ein europäisches Finanzzentrum zwischen Kontinuität und Umbruch', Berichte zur deutschen Landeskunde, 73(1), 67-93.

British Invisibles (1999) City Business Series 1999 Legal Services, December. London: British Invisibles.

British Invisibles (2000a) City Business Series 2000 Statistical Update Banking, March. London: British Invisibles.

British Invisibles (2000b) International Financial Markets in the UK, October. London: British Invisibles.

British Invisibles (2000c) World Invisible Trade, August. London: British Invisibles.

Castells, M. (1996) The Rise of the Network Society. Oxford: Blackwell.

Cohen, R.B. (1981) 'The new international division of labour: multinational corporations and urban hierarchy', in M. Dear and A.J. Scott (eds), Urbanization and Urban Planning in Capitalist Society. New York: Methuen, pp. 287-315. 
Corporation of London (1999) Competitiveness of London's Financial and Business Services Sector, September. London: Corporation of London.

Corporation of London (2000a) London - New York Study: The Economies of Two Great Cities at the Millennium, June. London: Corporation of London.

Corporation of London (2000b) The City's Importance to the European Union Economy Annual Report, November. London: Corporation of London.

Dicken, P. (1998) Global Shift: Transforming the World Economy, 3rd edition. London: Paul Chapman.

Dietl, H., Pauli, M. and Royer, S. (1999) Frankfurts Position im internationalen Finanzplatzwettbewerb: eine ressourcenorientierte Analyse, Working Paper 1999/10. Frankfurt am Main: Center for Financial Studies.

Freund, B. (2000) 'Deutschlands Hochhaus-Metropole Frankfurt', Frankfurter Statistische Berichte, 1/2000, 39-60.

Friedmann, J. (1986) 'The world city hypothesis', Development and Change, 17, 69-84.

Friedmann, J. and Wolff, G. (1982) 'World city formation: an agenda for research and action', International Journal of Urban and Regional Research, 3, 309-344.

Fröbel, F., Heinrichs, J. and Kreye, O. (1980) The New International Division of Labour. Cambridge: Cambridge University Press.

Grote, M.H. (2000) Frankfurt - An Emerging International Financial Centre, IWSG Working Papers 10-2000. Frankfurt am Main: Institut für Wirtschafts- und Sozialgeographie.

Grote, M.H., Harrschar-Ehrnborg, S. and Lo, V. (1999) 'Technologies and proximities: Frankfurt's new role in the European financial centre system', Working Paper Series: Finance \& Accounting, 46. Frankfurt am Main: Johann Wolfgang Goethe-Universität Frankfurt am Main, Fachbereich Wirtschaftswissenschaften.

Harrschar-Ehrnborg, S. (2001) 'Frankfurt hat als Finanzzentrum aufgeholt', BörsenZeitung, 12 January.

Häuser, K., Götz, R.-J., Müller, J. and Grandjean, B. (1990) Frankfurts Wettbewerbslage als europäisches Finanzzentrum. Frankfurt am Main: Institut für Kapitalmarktforschung.

Healey \& Baker (1999) European Cities Monitor. London: Healey \& Baker.

Healey \& Baker (2000) European Cities Monitor. London: Healey \& Baker.

HM Treasury (2000) Fourth Report on Euro Preparations, November. London: HM Treasury.

Holtfrerich, C.-L. (1999) Finanzplatz Frankfurt. Von der mittelalterlichen Messestadt zum europäischen Bankenzentrum. Munich: Beck. 
International Financial Services London (2001) International Financial Markets in the UK, April. London: IFSL (http://www.ifsl.org.uk/uploads/RP_IFM_4_2001.pdf, accessed 23 August 2001).

Jürgens, U., Naumann, K. and Rupp, J. (2000) 'Shareholder value in an adverse environment: the German case', Economy and Society, 29(1), 54-79.

Kampmann, C. (1997) 'Frankfurt am Main und London: Zwei historische Bankplätze zwischen Partnerschaft und Konkurrenz. Stellungnahme und Diskussion', in F. Bosbach and H. Pohl (eds), Das Kreditwesen in der Neuzeit: ein deutsch-britischer Vergleich. Munich: Saur, pp. 163-181.

Kennedy, R. (1991) London: World City Moving into the 21st Century. London: HMSO.

King, A.D. (1990) Global Cities: Post-imperialism and the Internationalization of London. London: Routledge.

Kroeger, F. and Rockenhaeuser, J. (2001) In Pursuit of Value-Building Growth. Chicago: A.T. Kearney.

Krugman, P.R. (1994) 'Competitiveness: a dangerous obsession', Foreign Affairs, 73(2), 28-44.

Landeszentralbank in Hessen (2000) Trends and Prospects for Foreign Banks at the Frankfurt Financial Centre, Frankfurter Finanzmarkt-Bericht 36. Frankfurt am Main: Landeszentralbank in Hessen.

Lascelles, D. (1999) Le Prix de l'Euro ... Competition between London, Paris and Frankfurt. London: Centre for the Study of Financial Innovation.

Laulajainen, R. (2001) 'End of geography at exchanges?', Zeitschrift für Wirtschaftsgeographie, 45(1), 1-14.

Llewelyn-Davies (1996) Four World Cities: A Comparative Study of London, Paris, New York and Tokyo. London: Llewelyn-Davies.

London Chamber of Commerce (2000) 'Euro "not an issue for the City - yet"'. Press notice and executive summary, 13 June. London: London Chamber of Commerce.

London Chamber of Commerce and Industry (2000) London - A Foreign Banking Perspective 2000: Executive Summary. London: London Chamber of Commerce.

London First Centre (1999) 100 Facts on London, October. London: London First Centre.

London First Centre (2000) The London Economy. London Business Briefing, Edition 2, May. London (www.Ifc.co.uk/downloads/134.pdf, accessed on 22 May 2001)

Maggiotto, R. (2000) Defining Tomorrow's Leading Financial Services Institution, March. New York: PricewaterhouseCoopers. 
Management Consultancies Association (2000) UK plc on the World Stage in 2010. Book 5: Technology and the New Workforce. London: Management Consultancies Association.

Reed, H.C. (1981) The Preeminence of International Financial Centers. New York: Praeger.

Reed, H.C. (1989) 'Financial center hegemony, interest rates and the global political economy', in S.Y. Park and M. Essayyad (eds), International Banking and Financial Centers. London: Kluwer, pp. 247-268.

Sassen, S. (1991) The Global City. New York, London, Tokyo. Princeton, NJ: Princeton University Press.

Sassen, S. (1994) Cities in a World Economy. Thousand Oaks, CA: Pine Forge Press.

Schamp, E. (1999) 'The system of German financial centres at the crossroads: from national to European scale', in E. Wever (ed.), Cities in Perspective I: Economy, Planning and the Environment. Assen: Van Gorcum, pp. 83-98.

Seifert, W.G., Achleitner, A.-K., Mattern, F., Streit, C. and Voth, H.-J. (2000) European Capital Markets. Basingstoke: Macmillan.

Taylor, P.J. (2001) 'Specification of the world city network', Geographical Analysis, 33(2), 181-194.

Taylor, P.J., Catalano, G. and Walker, D.R.F. (2001a) 'Measurement of the world city network', GaWC Research Bulletin, 43 (http://www.lboro.ac.uk/gawc/rb/rb43.html, accessed 23 August 2001).

Taylor, P.J., Catalano, G. and Walker, D.R.F. (2001b) 'Exploratory analysis of the world city network', GaWC Research Bulletin, 50 (http://www.lboro.ac.uk/gawc/rb/rb50.html, accessed 23 August 2001).

Taylor, P.J. and Hoyler, M. (2000) 'The spatial order of European cities under conditions of contemporary globalization', Tijdschrift voor Economische en Sociale Geografie, 91(2), 176-189.

Thrift N. (1994) 'On the social and cultural determinants of International Financial Centres: The Case of the City of London', in S. Corbridge, R. Martin and N. Thrift (eds), Money, Power and Space. Oxford: Blackwell, pp. 327-335.

Turner, B. and Reynolds, M. (2001) After the Euro: Three Changes to Take to the Bank. Chicago: A.T. Kearney. 